\title{
İşletmelerin İnsan Kaynakları Yönetimi Uygulamaları Üzerinde Covid-19 Pandemisinin Etkileri
}

DOI: 10.26466/opus.781324

*

\author{
Ayșen Akbas Tuna* - Onur Çelen ** \\ * Öğr. Gör. Dr., Ankara Hacı Bayram Veli Üniversitesi, Bankacılık ve Sigortacılık Yüksekokulu, Ankara \\ E-Posta: aysen.akbastuna@hbv.edu.tr \\ ORCID: 0000-0003-4615-4374 \\ ** Öğr. Gör., Bursa Uludağ Üniversitesi, Harmancık Meslek Yüksekokulu, Bursa / Türkiye \\ E-Posta: onurcelen@uludag.edu.tr \\ ORCID: $\underline{0000-0003-4601-2173}$
}

\section{Öz}

Çok kısa sürede tüm dünyayı etkisi altına alan COVID-19 pandemi sürecinden, her kesimden insan ve işletme etkilenmiştir. Yürürlüğe giren yeni uygulamalar ile insanların ve işletmelerin yaşam şekilleri değişime uğramıştır ve uğramaya da devam edeceği düşünülmektedir. İlgili süreçte işletmelerin insan kaynaklar uygulamalarının neler olduğu ve pandeminin ilgili uygulamalara etkisinin belirlenmesi son derece önem arz etmektedir. Bu çalışmada da işletmelerin insan kaynakları uygulamalarına COVID19'un etkileri belirlenmek istenmiştir. Yöntem olarak, yarı yapılandırılmış görüşme tekniği seçilmiştir. Konuya ilişkin alanında yetkin akademisyenlerce görüşme formu oluşturulmuş ve farklı sektörlerde görev almakta olan 51 insan kaynakları yöneticisi, insan kaynakları uzman ve firma yetkilisi ile görüşülmüştür. Katılımcılardan alınan bilgilerle, NVivo 11 paket programında, konuya ilişkin tema ve alt temalar oluşturulmuş ve cevaplanma sıkılığına göre tablolaştırılmıştır. Çalışmadan elde edilen bulgulara göre, firmaların ilgili sürece adapte olmak adına çeşitli faaliyetler gerçekleştirdiği, uygulamalarında internet sistemlerine ağırlık verdiğ i, çalışanlarm iş güvenliği için hijyen ve sağglk kontrolü gerçekleştirdikleri, devletten alınan destekler ve kendi imkanlarıyla çalışanlarına iş güvencesi sağlamaya çalıştıkları sonuçlarına ulaşılmıştır. Firmaların kariyer planlaması, kullandıkları kaynak ve yöntemler hakkında önerilere de çalışmada yer verilmektedir.

Anahtar Kelimeler: COVID-19, insan kaynakları yönetimi uygulamaları, insan kaynaklar yönetiminde teknoloji 


\title{
Human Resources Management Practices of Businesses in The Era Of COVID-19
}

\begin{abstract}
During the COVID-19 pandemic, which took effect all over the world in a very short time, people and businesses from all walks of life were affected. The way people and businesses Live has changed and will continue to undergo new practices. It is very important to determine the impact of COVID-19 on the related applications and what the human resources applications of the companies are in the related process. The effects of COVID-19 on the human resources practices of the companies were asked to be determined. As a method, a semi-structured interview technique was chosen. An interview form has been created by qualified academicians in the field of the subject. 51 human resources managers, human resources experts and company officials who are working in different sectors were interviewed. With the information obtained from the participants, themes and sub-themes related to the subject were created in the NVivo 11 package program and were tabulated according to the frequency of answering.

According to the study findings, it was concluded that companies carried out various activities in order to adapt to the relevant process, focused on internet systems in their applications, performed hygiene and health checks for occupational safety of employees, and tried to provide job security to their employees with the supports received from the state and their own means. Suggestions about the career planning of the companies, the resources and methods they use are also included in the study.
\end{abstract}

Keywords: COVID-19, practices of human resources management, technology in human resource management. 


\section{Giriş}

İnsan Kaynakları Yönetimi (İKY), işgücü, yetenek, planlama, performans, politikalar ve uygulamalar ile işletmenin kurumsal hedeflerine başarıyla ulaşmasını sağlayan stratejik öneme sahip ve süreklilik arz eden bir süreçtir (Huselid, Jackson ve Schuler, 1997, s. 171). İşletme açısından insanın yani çalışanın verimliliğinin yanında iş hayatının kalitesini arttırmak görevi de İnsan Kaynakları Yöntemi'ne (İKY) aittir. İnsan kaynakları yönetimi sayesinde düşünce, gelişim ve değişim aynı anda mümkün olabilmektedir. Gelişim ve değişimin temel noktasının insan olduğu dikkate alındığında, gelişimin ve değişimin en hakim olduğu alan insan kaynakları yönetimidir (Demirkaya, 2006, s. 1). Özellikle son yıllarda, insan kaynakları yönetimi; insanın, tüketilebilen ögeden ziyade, geliştirilmesi zorunlu olan bir değer olduğuna dikkat çekmektedir. Örgütün varlığı ve devamlılığı konusunda insan unsurunun hayati bir öneme sahip olması, sıradan bir fikir olmaktan sıyırılarak, stratejik bir değer olduğunun şirket yönetimlerince kabul görmesi, yönetimin insan unsuruna ağırlık vermesini sağlamıştır (Benli ve Şahin, 2004, s. 113-114).

İnsan kaynakları yönetiminden beklenenler; işgören devir hızını düşürmesi, çalışanların örgüte olan bağlllığını arttırmak, işten ayrılmaları düşürmek, işletmenin etkinliğinin yükseltilmesi ve örgütün performansını en yüksek düzeylere ulaştırmasıdır (Gürbüz ve Bekmezci, 2012, s. 190). Belirtilen amaçlar işletmenin çalışanı olan insanlardan beklentisidir. Aynı şekilde çalışanların da bağlı bulundukları işletmelerden çeşitli beklentileri bulunmaktadır. Çalışanlar bağlı bulundukları örgütlerde; istihdam edildikleri işlerinde kariyer olarak ilerlemek, aldıklarından daha fazla ücreti elde etmek, işleri ile ilgili konularda inisiyatif alabilmek, prestij sahibi olmak ve saygınlık görmek istemektedir. İşte bu tarz imkanların çalışanlara sunulması ve uygulanması da yine insan kaynakları yönetiminin görevleri arasında yer almaktadır (Taşliyan, Arı ve Duzman, 2011, s. 232-233).

İçinde bulunduğumuz yüzyılda yönetim anlayışı gelişim ve değişim göstermektedir. İlgili görüşün yaygınlaşmasında; "paradigma değişmeden, dünyanın değiş̧meyeceği" görüşü etkili olmaktadır. Sürekli değişim ve gelişimin yaşandığı bir dönemde yöneticiler, doğru kişilerin başarılı bir şekilde, doğru işleri yapmalarını sağlamak durumundadır. Ancak işletmelerin ve çalışanların performansları üzerinde beklenmeyen durumlar oluşabilmekte ve bu du- 
rumlar olumsuz etkilere sebebiyet verebilmektedir (Öztürk, 2010, s. 2). İşletmelerin ve işgörenlerin performansları üzerinde çeşitli değişmelere neden olabilen çevresel faktörlere karşı işletmeler, çeşitli önlemler almak durumundadır. İşletmelerin aldıkları önlemler çevrede meydana gelen değişmelere uyum sağlayacak ve cevap verebilecek nitelikte olduğu sürece, başarılı olabilecektir (Dereli, 2005, s.60).

Hizmet sektöründeki işletmeler açısından dikkate alındığında ise konu, gelişimlere ayak uyduracak şekilde insan kaynaklarında aranan özellikleri ve yetkinlikleri değiştirebilmektir. Değişime uyum sağlayabilmek, değişecek isteklere tatmin edici cevapları verebilmek, her durumda kendini bir şekilde hissettiren rekabet ortamında kaliteli ürün ve hizmeti ortaya çlkarabilmek ve bunları yaparken de müşteri memnuniyetini sağlayabilmek gittikçe zorlaşmaktadır (Tütüncü ve Demir, 2003, s.147). Sanayileşme ile birlikte teknolojik ve çevresel alanlarda meydana gelen gelişmeler, yeni ihtiyaçları doğurmakla kalmayarak, işletmelerin ilgili konularda kendilerini değiştirmelerini, yeni çalışma ortam ve kurallarını, farklı üretim tekniklerini ve iş tanımlarını yenilenmesini zorunlu kılarak, işletmelere ve çalışanlara yönelik çağdaş uygulamaları da ortaya çıkarmaktadır. Bilimsel ve teknolojik gelişmelerle, işgören seçiminde, işlerin nitelik, nicelik ve biçiminde farklılaşmalar olabilmektedir. Bu durumda işlerde yeni işleyiş formatlarıyla, nitelikli işgörenin temini ve eldeki nitelikli işgörenlerin de işletmede tutulması gerekmektedir (Saldamlı, 2008, s.240).

İnsan kaynakları yönetiminin yerine getirmesi gereken çok sayıda görevi olduğu anlaşılmaktadır. Bilhassa her türlü değişimin ve olayın yaşandığı piyasalarda işletmeler, karşılaştıkları olumsuz durumları en az zararla atlatmak durumundadır. Küresel ölçekte sağlik konusunda yaşanan olumsuz olaylar hem insanların sağlığını tehdit etmekte hem de işletmelerin varlıklarını ve faaliyetlerini olumsuz olarak etkilemektedir. 2019 yılının sonlarında dünyaya yayılmaya başlayan COVID-19 salgını, tüm dünyayı etkisi altına alarak, çok sayıda işletmenin faaliyetlerini durma noktasına getirmiştir. Pandemi sürecinde, iş sağllğı ve güvenliği de insan kaynakları yönetimini ilgilendiren diğer konuları oluşturmaktadır. Bu durum, insan kaynakları yönetimi faaliyetlerinde çeşitli değişmeler olacağını düşündürmektedir. Dolayısıyla, bu süreç içerisinde ve ilerleyen dönemler için insan kaynakları yönetiminin mevcut durumu ve ilgili durumlara göre yapılması gerekenler, son derece önemlidir. 
Çalışmanın temel amac1; içinde bulunduğumuz COVID-19 salgını sürecinde işletmelerin insan kaynakları yönetim sürecinin incelenmesidir. İşletmelerin, insan kaynakları planlama ve uygulamalarının nasıl olduğu, pandemi sürecinde işe alım ve personel tedariğinde nelere dikkat edildiği, iş sağlığı ve güvenliği uygulamalarının neler olduğu, pandemi süreci ve sonrasında personel sayısında artma ve azalma olup olmayacağı gibi konular hakkındaki görüşlerin ortaya konması ve insan kaynakları yönetiminde meydana gelebilecek değişmelerin belirlenmesi de hedeflenmektedir. Araştırmanın veri toplama sürecinde nitel araştırma yöntemlerinden dijital ortamda görüşme tekniği kullanılmıştır. İşletmelerin insan kaynakları yöneticilerinden toplanan bilgiler, içerik analizi yöntemiyle, sınıflandırılmıştır. İlerleyen dönemlerde benzer pandemi salgınları ve krizler için insan kaynakları yönetimi alanında yapılması gerekenlerin ortaya konulması da son derece önemlidir. Araştırmaya göre insan kaynakları yönetimi konusunda proaktif yaklaşımların belirlenmesi ve uygulanmasıyla işletmelerin beklenmedik durumlara karşı hazırlıklı olabilecekleri ve ilgili süreci en az zararla atlatacakları düşünülmektedir.

\section{Literatür İncelemesi}

\section{İnsan Kaynaklan Yönetimi}

İnsan kaynakları yönetimi en geniş tanımıyla; "bir örgütün en değerli varl1ğının, yani insanların etkili yönetimi için geliştirilen stratejik ve tutarlı bir yaklaşım" olarak tanımlanmasının yanı sıra, "Örgüt içinde bulunan işgücünün memnuniyeti, gelişimi, motivasyonu ve yüksek performansın sürekliliğinin sağlanması için üstlenilmiş etkilerin yönetimidir" şeklinde de tanımlanmaktadır (Akbaba ve Günlü, 2011, s. 203-204). İnsan kaynakları yönetimi; çevresel ve örgütsel ortamda insan kaynaklarının örgüte, çevreye ve kişiye fayda sağlayacak biçimde ve ayn zamanda kural ve kaidelere uyularak, verimli ve etkili yönetim prosedürlerinin tümüdür. İnsan kaynaklarının en temel görevi; örgütün hedeflerine en verimli şekilde ulaşılmasını sağlamaktır. İlgili hedefin gerçekleşmesi için de insan kaynakları yönetimi insan ilişkilerine yönelmiştir (Akçadağ ve Özdemir, 2005, s. 170).

İnsan kaynakları yönetimi, örgütün hedeflerine ulaşmayı sağlayacak işgücünü bulan, yönlendiren ve bu faaliyetleri yapacak kişilerin de yine insan 
olmasına bağlı olarak karmaşık yapıdaki bir sistemdir (Mikhaylov, Julia ve Eldar, 2014: 330-331). İnsan kaynakları yönetimi bu açıdan hedefleri belirleyebilir, değiştirebilir ve örgüt içerisindeki bireylerin davranışlarını doğrudan etkileyebilir (Ledzion, 2015, s. 675).

İnsan kaynakları yönetimi etkili bir şekilde kullanıldığında; rekabetçi anlayış, kültürel ve çevresel bakımdan heterojen olabilen iş gücünü, verimli olarak yönlendirip, diğer işletmeler karşısında rekabet üstünlüğü sağlayabilmektedir. İfade edilen yönetim anlayışı yönetim bilimi literatüründe; "olumlu faaliyet programları" olarak isimlendirilmektedir. Proaktif faaliyetler şeklinde de adlandırılan bu programlar; güç durumların ve farklılıkların nasıl olumlu bir yöne evrilebileceğini, işgörenlerin seçimi ve eğitimi, işgören geliştirme, işgörenlerin performanslarının yönetimi, kariyer süreci ve benzeri İnsan Kaynakları Yönetimi uygulamalarından yararlanarak açklayan programlardır (Helvacıoğlu ve Özutku, 2010, s. 202).

\section{İnsan Kaynaklarn Yönetimi Uygulamalarn}

İnsan kaynakları yönetimi uygulamaları bölümünde süregelen uygulamalarla birlikte pandemi sürecinde bir zorunluluk haline gelen elektronik ortam kullanımı ve elektronik ortamda insan kaynakları konulara değinilmiştir.

İnsan Kaynaklan Yönteminde İşgücü Planlaması ve Isşe Alım Süreci : İKY açısından işgücünün planlanması, işletmenin ilerleyen dönemlerde pazar, ürün ve süreçlerde meydana gelecek değişmeleri kapasite, miktar, talep ve özelliklere göre değerlendirmesidir. İlgili duruma bağlı olarak, örgütlerin gelecek zaman dilimleri için mal ve hizmetlerin talep ve kapasite tahminlerinin gerçekleştirilmesi; işgücünde emeklilik, istifa, işe son verme ile ileride işgücünde yaşanacak daralmanın önüne geçilmesi, geleceğe yönelik iş işgücü açığ1 tahminin yapılması; teknolojik değişmelere uygun işgücü nitelik ve özelliklerinin belirlenerek, örgütün ilgili işgücünü sağlayabilmek adına, mali yetenek analizinin gerçekleştirilmesi gerekmektedir (Akbaba ve Günlü, 2011, s. 208).

İnsan kaynakları yönetiminde, işe alım sürecinde ise adayların, öğrenmeye ve zor şartlara adapte olarak örgütün varlığını koruyucu nitelikte faaliyetlerde bulunabilecek yapıda olmaları son derece önemlidir. İşe alım sürecinde yetki sahibi olan kişilerin, sadece örgüte adapte olacak kişileri seçme 
eğiliminde olmaktansa, farklı ve proaktif kişileri de tercih etmeleri, örgütün devamlılığı, yeni fikirlerin oluşması ve kriz dönemlerinin atlamalarında fayda sağlayacaktır. Bu durumun örgüte sağlayacağı önemli bir diğer fayda ise örgütün bu kişiler vasıtasıyla örgütsel öğrenme sağlaması olacaktır (Özer, Özmen ve Saatçioğlu, 2004, s. 267).

İşletmeler başarılarının devamlılığını sağlayabilmek için nitelikli işgücünü işletmeye almasının yanı sıra, nitelikli işgücünü de elinde tutması da gerekmektedir. Nitelikli iş gücünün potansiyel, beceri ve bilgisinin yüksek olması, işgücünü stratejik bir değere dönüştürmektedir. Nitelikli işgücünün işletmeye alınması ve elde tutulmasıyla, işletmenin beklenen ve beklenmeyen durumlara karşı, uygulayacağı faaliyetler de stratejik önem kazanmaktadır. Bu sayede işletmeler, krizleri daha rahat atlatabilmektedir. Ayrıca, nitelikli işgücünün elde tutulmaması işten ayrılmaya dolayısıyla maliyetlerin artmasına neden olabilmektedir (Altınöz, 2018, s. 82-83).

İKY'de İşgören Eğitimi ve Geliştirilmesi: İnsan kaynakları açısından eğitim önemli bir yere sahiptir. İşletmenin temeli olan, işgören bilinci ve ilgili kaynağın etkin ve verimli bir şekilde kullanılabilmesi eğitime ve geliştirilmesine bağlıdır. Özellikle içinde bulunduğumuz dönemde, eğitim ve işgörenlere verilecek eğitim bilinci giderek artmaktadır. Çağımızın bir zorunluluğu olarak da işgören eğitimi ile işletmenin ve faaliyetlerinin devamlılı̆̆ı, kalite ve verimliliğin arttırılması ve sınırsız rekabet ortamı ile mücadele edebilmek, mümkün olmaktadır (Bek, 2002, s. 44).

Örgüt içerisinde işgörenlere yetenek, beceri ve bilgiler eğitim ile kazandırılabilmektedir. Özellikle stratejilerde meydana gelen değişiklikler, genel olarak, beceri düzeyi ve türleri ile beceri karmasında farklılaşmalara neden olabilmektedir. Bu nedenle eğitim ve geliştirme kararlarının, örgütün ihtiyaç duyacağı beceri ve bilginin temini, işgörenlerin üst düzey potansiyeline ulaşmalarını sağlayıcı kararlar olduğu ifade edilebilir (Bayraç, 2008, s. 93).

İşörene verilecek eğitim, örgütün çıkarları için bilgi-beceri üzerine olabileceği gibi iş sağllğı ve güvenliği şeklinde de verilmektedir. Çünkü burada hem işgörenlerin hem de örgütün korunması önemlidir. Çalışma ortamının sağlıksız olmasından öncelikle işgörenler etkiletmektedir. İçinde bulunduğumuz pandemi döneminde ilgili konulara vurgu yapılması gerekmektedir. $\mathrm{Bu}$ dönemde işgörenlerin ve ailelerinin gelir seviyesinde yaşanabilecek düşüşler 
vb. nedenler, psikolojik olarak da olumsuz etkiler yaratabilecektir (Karacan ve Erdoğan, 2011, s. 104).

ÍKY'de Performans Değerlendirme: Venkateswara Rao (2016) çalışan performansını "Bireysel Performans $=$ Yetenek $\times$ Motivasyon $\times$ Örgütsel Destek + Şans Faktörleri" şeklinde formüle etmiş̧ir. Burada yetenek ile ilgili yeterlilikler, bilgi, tutum, değer ve beceri yoluyla yansitılan teknik ve yönetimsel beceriler, insan ilişkileri, kavramsal ve soyut düşünme olarak tanımlanırken; motivasyonun ise sıkı çalışma ve bağlılık yoluyla yansıtıldığı görülmüştür. Örgütsel destek ise çalışanın işini iyi yapabilmesi için yöneticisi ve örgütteki diğerlerinden ne kadar destek aldığıdır. Tüm bunlarla birlikte "Çalışanın ne yapması ve başarması gerekiyor?" sorusu performansın belirlenmesinde ortaya çıkmaktadır (Akbaş Tuna, 2020, s. 1837).

Genel olarak performans değerlendirme; işgörenlerin potansiyelini, kabiliyetlerini, iş içerisinde davranış ve alışkanlıkları ve eş özelliklerini diğer çalışma arkadaşlarıyla karşılaştırma şeklinde gerçekleştirilen ölçme sistemidir. Farklı bir tanımlamayla; iş görenlerin işe yönelik kabiliyetlerinin, iş içerisindeki tavır ve tutumlarının, yapılması istenen işin özelliklerine ne derecede yakın olduğunun incelenmesidir. Gerçekleştirilen bu analiz neticesinde, örgüt içerisinde sahip oldukları sıfatlara bakılmaksızın, fazlalıkları, eksiklikleri, yetersizlik ve etkinlikleri gibi tüm yönlerinin belirlenebilmesi mümkün olabilmektedir (Pehlivan, 2008, s. 172).

Performans değerlendirmesi sadece çalışanların değerlendirilmesi anlamına gelmemektedir. İlgili değerlendire ayrıca insan kaynakları faaliyetlerinin de sınanması anlamına demektir. Değerlendirme neticesinde, ortaya çıkan düşük başarı, işgören seçimi, eğitimi veya geliştirme faaliyetlerinde eksikler olduğunu göstermektedir. Dolayısıyla, ilgili faaliyetlerin, işletmenin ve işgörenlerin performansını arttıracak şekilde revize edilmesi gerekmektedir (Küçükkaya, 2006, s. 23).

Performans değerlendirme sistemlerinin temel niceliği, kişiler arasındaki değişiklik gösteren başarı derecelerini incelikle belirlemesidir. Burada amaç, ulaşılan sonuçların değerlendirilmesine yardımcı olmaktır. Performans değerlendirmede ayrıca, değerlendirilen kişinin kendisi değil, kişilerin örgüt içerisinde sergiledikleri performanslarıdır. Gerçekleştirilen değerlendirmeler, ücret üzerinden ödüllendirilebilmektedir. Performansı iyi olan kişilerin sosyal ve maddi açıdan desteklenmesi gerekir. Ayrıca stratejik planlamada, 
kariyer yönetiminde, iş geliştirme ve rotasyon gibi konularda, performans değerlendirme kilit rol oynamaktadır (Ferecov, 2003).

\section{İnsan Kaynakları'nda Teknolojik Eğilimler ve İKY'deki Etkileri}

Bilgi değişiminin çok yönlü boyut kazandığı günümüzde, insanların ve işletmelerin birbirleriyle iletişim kurma şekilleri ve işlevleri de yeni bir boyut kazanmıştır. İnternetin gelişimi ve insanların hayatına getirdiği yenilikler, insanların ve örgütlerin davranış ve faaliyetlerini de şekillendirmektedir. Teknolojik gelişmelerin ve internetin getirdiği ilgili özellikler, örgütlere insan kaynakları yönetimi hususunda çeşitli imkanlar sağlamaktadır (Ünal ve Çelen, 2018, s. 608).

Örgütlerde meydana gelen, teknolojik, sosyal ve ekonomik değişimlere adapte olabilmeleri, insan kaynaklarına stratejik önem vermelerine ve insan kaynaklarının da bu değişimlere cevap verebilmesine bağlıdır (Koçak ve Erdoğan, 2011: 263). İşletmeler açısından yukarıda sayılan etmenlerin uygulamaya dönüştürülme zorunluluğu; yapısal değişimler ve küreselleşmenin bir sonucudur. Yapısal ve küresel ölçekte yaşanan her türlü gelişme, işletmelerin varlıkları ve devamlılıkları için yapılması gerekenleri sunmaktadır. Ortaya çıkan bu yeni yönelimler, çoğu zaman dış çevrede yaşanan gelişmeler, iç çevrede yeni gelişmelerin olması gerekliliğine dikkat çekmektedir. Ortaya çıkan gelişmeler; örgütler için yönetsel ve yapılarını, düzenleme ve ihtiyaç görülen alanlarda yenilemeyi getirmiştir. Küresel ölçekteki yenilikler, istihdamı, istihdam edilen alanları ve tanımları, işgücü tedariğinde yeni teknikler, ulusal ve küresel anlamda, insan kaynakları yönetimi fonksiyonlarını şekillendirmektedir (Yapıcı-Akar ve diğerleri, 2011, s. 97).

Teknolojik gelişmeler ile insan kaynakları yönetiminde meydana gelen değişiklikler sadece web-tabanlı sistemler ile sınırlı değildir. Özellikle, Endüstri 4.0 insan kaynakları yönetiminde çeşitli değişiklere neden olmuştur (Dengiz, 2017: 39). Endüstri 4.0 ile örgütler, yenilikçi iş yaşamını benimseyerek, yenilikçiliği olumlu yönde etkilemeli ve pozitif sonuçlar elde etmelidir. Bunun için geleneksel yaklaşım bilgi ve yatırımlardan vazgeçilerek, organizasyona yeniliği ve farklılı̆̆ getirecek bilgiler temin edilerek ve kullanılan yeni bilgilerden tecrübe sağlanarak oluşan yeni temel aracılığıyla yeni uygulamalar hayata geçirilmelidir (Davutoğlu, 2018, s.4042). Endüstri 4.0, işgü- 
cünde değişme, iş tanımlarında yenilikler, ürün ve hizmetlerin oluşturulmasinda yenilikler, makineleşme, akıllı robotlar ve uygulamalarla klasik insan kaynakları yönetiminde çeşitli değişiklikleri sağlamaktadır (Parham ve Tamminga, 2018, s. 179-180).

İnsan kaynakları yönetimi açısından teknolojik alanda meydana gelen; web tabanlı ve endüstri 4.0 gibi otomasyon ve makineleşmeye olanak sağlayan yeni sistemlerin, insan kaynaklarını nasıl etkileyeceği, özellikle iş kollarındaki dışsal etkenler karşısında ifade edilen sistemlerin insan kaynakları yönetiminde yaratacağı etkilerin belirlenmesi son derece önemlidir. Dışsal etkilerle örgütler, zorunlu olarak çevreye adapte olmalıdır. Adapte olamadıkları takdirde, örgütün faaliyetleri ve varlığı tehlikeye girebilmektedir. Özellikle örgütlerin faaliyet gösterdiği ekonomik sistemlerde, yaşanan beklenmeyen olaylar, işlerin işleyişine, yeni iş tanımlarına bağlı olarak yeni iş görenlere ve eldeki nitelikli işgücünün elde tutulmasını, işgören tedariği ve yeni gelişen konularla ilgili eğitimi gibi konularda farklılaşmayı zorunlu kılmaktadır.

E-İKY Kavramı ve IKKY'deki Etkileri: Elektronik İnsan Kaynakları Yönetimi (E-İKY) ile ilgili çok sayıda tanım bulunmaktadır. En yalın haliyle E-İKY; örgüt tarafından, web temelli teknoloji ve gelişmelerin kullanılması ve uygulanması sayesinde insan kaynakları stratejileri, politikaları ve süreçlerini yönetebilme faaliyetleridir (Dülek, 2018, s. 18). Teknoloji ile bütünleşen insan kaynaklarında çeşitli kapsamlar oluşmuştur. İlgili kapsamlar (Allahverdi, 2006, s. 26):

1. Çok amaçlı örgütsel iletişimi sağlayabilmek ve yönetmek,

2. Öğrenme, bilgi, ödül, disiplin gibi konularda şeffaf bir alan tasarlayabilmek ve uygulamak,

3. Daimi yenilik, gelişim ve öğrenme süreçlerinin açk bir hale kavuşmasıyla, güçlü örgüt kültürünün oluşturulması,

4. Teknolojik gelişmeleri, stratejik bir avantaja dönüştürmek,

5. Kariyer ile ilgili ücret, planlama, performans denetimi ve eğitim geliştirme sistemlerini bir arada tasarlamak ve kullanabilmektir.

İnsan kaynakları yönetimi, politikaları ve uygulamaları açısından, işletmeler için itici güç olan E-İKY'nin örgüt yapıları içerisindeki kullanımı ve olgunlaşma süreci devam etmektedir (Ruel, Bondarouk ve Looise, 2004, s. 364; Ruel, Bondarouk ve Van der Velde, 2007, s. 280). E-IKKY, insan kaynakları uy- 
gulamalarını otomatikleştirmek, geleneksel kağıt kalem ve yoğun emek gerektiren görevleri, şirketlerin çok ihtiyaç duyulan bir rekabet avantajı haline getirmek için çevresel değişimleri öngörebilmenin ve kazanç sağlayabilmenin etkin ve hizlı bir yoludur (Olivas-Lujan, Ramirez ve Zapata-Cantu, 2007, s. 418).

1990 'l1 senelere gelinmesiyle birlikte, giderek yayginlaşmaya başlayan elektronik işe alım, teknolojiyi iyi kullanabilen işletme ve işgören adayları için çok verimli bir uygulamadır. Doğrudan ve dolaylı internet siteleri aracılığıyla, her türde iş tanımına uygun, işgücü adayları bulunabilmektedir. Elektronik işe alım; aday havuzunun oluşumunu kolaylaştırması, işe alım ve ilan verme gibi konular açısından ucuz bir kaynak olması, klasik işe alım sürecine nazaran süreci hızlandırması bakımından da oldukça verimli ve tercih edilen bir sistemdir (Dülek, 2018: 24). İşe yeni alınan ve mevcut işgörenlerin eğitimi ise elektronik ortamda, klasik sınıf ortamında öğrenmeye çok boyutluluk kazandırarak, internet, bant yayını, e-posta ve kompakt disk ile verilen eğitimler sayesinde huzlı bir şekilde gerçekleştirilebilmektedir (Allahverdi, 2006, s. 34).

Sıra işgörenlerin performansını değerlendirmeye geldiğinde ise elektronik uygulamalar kilit rol oynamaktadır. Elektronik performans sistemleri, yapılan iş miktarı, meydana gelen hatalar, işlerin gerçekleştirilmesi için harcanan süre gibi çeşitli bilgilerin kayıt altına alınmasını sağlamaktadır. Yöneticiler ilgili sistem sayesinde, kendilerine bağlı olarak çalışan işgörenlerinin, davranışlarını analiz edebilmekte ve performansını değerlendirirken meydana gelen zaman kaybının da önüne geçebilmektedir. Dolayısıyla ilgili sistem, hızlı geri bildirim almada son derece etkili olmaktadır (Esen, 2011, s. 45).

İnsan kaynakları yönetiminde elektronik anlamda ortaya çıkan yenilikler ücretlendirme sistemini de olumlu yönde etkilemiştir. Örgütte geçirilen zaman, işe devamlılık, performans değerlendirmeleri gibi etmenlerin, elektronik sistem üzerinden gerçekleştirilmesi, ilgili etmenlerin takibini de kolaylaştırmıştır. Bu durumda çalışanların performanslarına göre, ücretlendirme sistemi ve ödüllendirilmesi teknolojik olarak takip edilmeleriyle yakından ilgilidir. İlgili sistemde bürokrasi ve ofis işlemlerinin azalması da sistemin diğer olumlu yanlarını oluşturmaktadır (Alcan, 2019, s. 47-48).

E-IKYY'ye adapte olunması ile birlikte, kariyerlerini şekillendirmek isteyen işgörenler için çeşitli olumlu etkiler ortaya çıkabilmektedir. E-İKY, kariyer planlaması işletme içinde ve dışında bulunan iş alanları hakkında işgörenlere 
bilgiler verilmesi, gelişen ve değişen dünya şartlarına uygun eğitim programlarının tasarlanması ve alınmasını da sağlamaktadır. İşgörenler bu sayede yeni beceriler elde edebilmektedir (Esen, 2011, s. 48-49).

Endüstri 4.0 ve IKKY'deki Etkileri: Ana hatlarıla; iş ve iş süreçlerinde meydana gelen, dijital dönüşümü ifade etmek için kullanılan endüstri 4.0 biraz daha kapsamlı olarak ifade edilecek olursa; iletişim ve bilgi teknolojilerinin, üretim sistemleriyle koordineli hale getirilmesidir. Endüstri 4.0'ın en tipik özelliği; akıllı üretim uygulaması olmasıdır. Kavram, 2011 yılında Hanover'da düzenlenen bir fuarda duyulduktan sonra, birçok çalışmaya konu olmuştur (Filizöz ve Orhan, 2018, s. 111).

Endüstri 4.0'1, oluşturan temel bileşenlerden birincisi; düşük maliyetli, az enerji harcayan, yüksek güvenilirlikte çalışan, düşük hacime sahip, "yeni nesil yazılım ve donanım"dır. Bir diğeri de teknolojik aletlerin birbirleriyle iletişim kurarak bilgi akışının sağlanabildiği, araç-gereç olarak bütünleşik yapı içerisinde olabilen, işletici ve sensörlerle desteklenen, internet bağlantılı akıllı elektronik sistem olan "nesnelerin interneti" dir. Son bileşeni ise siber-fiziksel sistemlerdir. Üretim aşamasında ilgili sistemler, insanlardan ayrı bir şekilde kendilerini eşgüdümleyebilen ve en uygun seviyeye getiren akıllı sistemlerdir (Yllmaz ve Erkollar, 2018).

Dünyanın küreselleşme sonucunda büyük bir köye dönüşmesi, örgütlerdeki insan kaynakları birimlerinin ihtiyaç duyacakları bilgileri depolaması ve işleyebilmesi için dijital sistemlere geçiş yapmaktadır. İnsan kaynakları yönetiminin ihtiyaç duyacağı bilgilere ulaşmasına olanak sağlayan sistemlerden birisi, bulut sistemdir. İlerleyen dönemler için örgütler ve insan kaynakları birimlerinin değerini arttıracak sistemler; endüstri 4.0 ve bulut bilişim sistemleri olacaktır ve bu sistemler özellikle insan kaynakları birimi için stratejik öneme sahiptir (Göktaş ve Baysal, 2018: 1420). Endüstri 4.0'ın özellikle hizmet sektöründe yer alan işletmeler açısından, hizmet interneti kavramı dikkat çekmektedir. İlgili ifade; hemen hemen hiç insan etkisi olmadan, tüm işlem basamaklarında, ürün ve hizmetlerin nereden nereye, ne zaman ve nasıl gitmeleri gerektiğine kendilerinin karar alması ve uygulamasıdır (Yıldız ve Davutoğlu, 2018, s. 1567).

Endüstri 4.0'1 değişimin ve gücün rehberi olarak kabul eden örgütlerin insan kaynakları birimleri, yapay zekaya sahip robotlarla iş paylaşımı, yeni öğ- 
renme şekilleri, elektronik öğrenme gibi kavramlar işletmelerin yüksek düzeyde esnek bir yapıya kavuşmalarına olanak sağlayacaktır. Sahip olunan bu esneklik ile üretimde yenilikçi standartlara sahip akıllı fabrikalar aracilığıyla çalışanların daha verimli kararlar alabilmesi mümkün olacaktır. Güncel iş tanımlarına göre istihdam edilenler daha yaratıcı sorular sorarak, makinelerin daha iyi cevaplar verebilmesini sağlayacaktır (Davutoğlu, 2018, s. 4046).

E-İKY hakkında yapılan çalışmalar incelendiğinde şu araştırmalara rastlanmıştır. Ruel, Bondarouk ve Looise (2004) çalışmalarında; insan kaynakları yöneticilerinin E-İKY uygulamalarını, örgütsel amaçlara ulaşmada nasıl kullandıkları, E-İKY uygulamalarının örgütlerde bir çeşitlilik yaratıp yaratmayacağı ve E-İKY ile İKY uygulamalarının ortak noktalarının neler olabileceği soruları üzerinde durmuştur. Çalışma kapsamında elde edilen bulgulara göre, örgütlerin E-İKY üzerinde web tabanlı sistemlerin, stratejik bir değere sahip olduğu, işletmelerde yeni iş tanımların beraberinde getirdiği ve işe alım, personel seçimi konularında klasik İK faaliyetleriyle benzerlik olsa da çeşitlilik sağladığı sonuçlarına ulaşılmıştır. Allahverdi (2006) yüksek lisans tezinde; Türkiye'deki 100 büyük işletmesinin E-IKKY kullanımını araştırmıştır. Araştırmaya dahil olan işletmelerin tamamının bilgi edinme ve bilgiyi kullanma süreçlerinde E-İKY faaliyetlerinden yararlandığı sonucuna ulaşılmıştır. Ruel, Bondarouk ve Van der Velde (2007) araştırmalarında ise E-İKY'nin değerlendirilmesi ve daha spesifik anlamda, E-İKY araçlarının işle ilgisi, kalitesi ve kullanım kolaylığının teknik ve stratejik anlamda İKY' yi olumlu yönde etkilediği hipotezi üzerinde durmuştur. Araştırma neticesinde, E-İKY araçlarının kaliteyi olumlu yönde etkilediği ancak doğrudan stratejik ve teknik anlamda bir katkısı olmadığı sonucuna ulaşılmıştır. Olivas-Lujan, Ramirez ve Zapata-Cantu (2007)'nun araştırmasında; E-İKY uygulamalarının Meksika'daki işletmelerin İKY faaliyetlerine etkisi ve rekabet avantajı sağlayıp sağlamadığı soruları üzerinde durulmuştur. Araştırmadan elde edilen sonuçlara göre, E-IKKY uygulamalarının olumlu etkileri olduğu ve rekabet avantajı sağladığı tespit edilmiştir. Karacan ve Erdoğan (2011)'ın araştırmasında ise iş sağlığı ve iş güvenliğine insan kaynakları yönetimi fonksiyonları açısından kavramsal bir inceleme gerçekleştirmiştir.

Davutoğlu (2018) çalışmasında, endüstri 4.0'ın liderlik ve insan kaynakları yönetimine algisal etkisini belirlemek amaciyla kavramsal bir inceleme gerçekleştirmiştir. Dülek (2018) yüksek lisans tezinde, E-İKY uygulamalarından, 
İKY yöneticileri memnun mudur? sorusuna cevap aramaktadır. Araştırmadan elde edilen bulgulara göre, yöneticilerin, E-IKKY sistemlerinden memnun oldukları sonucuna ulaşılmıştır. Göktaş ve Baysal (2018) çalışmasında Endüstri 4.0 - Bulut Bilişim'in insan kaynakları yönetimi üzerindeki etkisiyle ilgili kavramsal bir inceleme gerçekleştirmiştir. Yıldız ve Davutoğlu (2018)'da çalışmasında konaklama işletmelerinde personel ve insan kaynakları yönetiminde endüstri 4.0'in incelenmesi ile ilgili kavramsal bir inceleme gerçekleştirmiştir. Yılmaz ve Erkollar (2018) çalışmalarında, Endüstri 4.0'ın insan kaynakları planlaması üzerine kavramsal bir inceleme gerçekleştirmiştir.

\section{Yöntem}

Araştırmanın bu bölümünde, araştırmanın soruları, araştırmanın yöntemi çalışma grubu, yararlanılan veri toplama tekniği ve verilerin analizi ile ilgili bilgilere yer verilmektedir. Çalışmada, NVivo 11 paket programına, iki farklı araştırmacı tarafından veri seti giriş işlemi gerçekleştirilmiş ve elde edilen tema, alt tema ve ifadeler karşılaştırılmıştır. NVivo 11 paket programında yapılan karşılaştırmalar neticesinde Cohen kappa katsayısının 0,88 olduğu anlaşılmıştır. Cohen Kappa katsayısının -1 ile +1 aralığında bulunması gerekmektedir. +1 'e yaklaştıkça karşılaştırmanın güvenilir yani mükemmel bir uyuşma olduğu sonucuna ulaşılmaktadır. Dolayısıyla çalışmadaki tema, alt tema ve ifadelerin güvenilir olduğu söylenebilir (Sevim ve Ayvacı, 2020, s. 29).

Yukarıda da belirtildiği üzere, E-İKY, İKY ve Endüstri 4.0 ile ilgili olarak çok sayıda çalışma gerçekleştirilmiştir. İnsan kaynakları yönetimine zorunlu da olsa yeni bir yaklaşım getirebilecek olan COVID-19 salgını ise bu süreçte incelenmeye çalışılan çok yeni bir kavramdır. Bu doğrultuda araştırmanın problemi "COVID-19 salgınının, insan kaynakları yönetimi faaliyetleri üzerindeki etkileri nelerdir?" ve "İnsan kaynakları yönetiminde meydana getireceği değişmeler nelerdir?" ifadelerinden oluşmaktadır.

Çalışmada veri toplama aracı olarak, nitel veri toplama tekniğine başvurulmuştur. Nitel araştırmalarda önemli olan, elde edilen çıktılardan daha çok sürecin kendisidir. Çalışmada, yarı yapılandırılmış görüşme tekniği kullanılmıştır.

Nitel araştırmalarda, ifadeler ve ifadelerden sağlanan anlamlar değer kazanmaktadır. Araştırmacılara esneklik ve standartları aracılığıyla belirli 
oranda avantajlar sağlayan yarı yapılandırılmış görüşme tekniği; güncel, detaylı bilgi ve görüş alınmak istenen konularda kullanılmaktadır. Katılımcılardan detaylı ve kapsamlı bilgi teminini mümkün kılan, yarı yapılandırılmış görüşme tekniği daha etkili olduğundan, araştırmacılar tarafından kullanılabilmektedir (Altunay, Oral ve Yalçınkaya, 2014, s. 67).

Sosyal bilimlerde, kurulan iletişimin niceliksel, nesnel ve sistematik olarak ele alınması içerik analizinde analitik sınıflandırmanın nesnellik, ayn konuyu araştıran farklı araştırmacıların, aynı içeriği incelenmesiyle benzer sonuçlara ulaşması olarak ifade edilmektedir. İfade edilmeye çalışılan görüşün özü; çalışma sonucunda elde edilen verilerde, araştırmacıların kendi subjektif görüşlerinin yer alamamasıdır (Çelen ve Tuna, 2018, s. 414).

\section{Çalışma Grubu}

Çalışmada görüş ve fikirleri alınacak çalışma grubunun belirlenmesinde, amaçlı örnekleme yöntemlerinden "ölçüt örnekleme" yönteminden yararlanılmıştır. Ölçüt örnekleme; örneklemin ilgili soruna bağlı şekilde uygun bireylerin, nesneleri, olayları yada süreci meydana getiren bireylerden belirlenmesidir (Tuna ve diğerleri, 2018, s. 372-373). Saha çalışması kısmında, insan kaynakları yönetimi konusunda bilgi sahibi olan yöneticiler, özel şirketlerdeki ilgili birimin yöneticileri, kamu kurumunda insan kaynaklarından sorumlu yetkililer, konuyla ilgili görüss sahibi STK yöneticilerinin de yer almasına özen gösterilmiştir.

İçinde bulunduğumuz COVID-19 salgın sürecinde insan kaynakları yöneticilerinin, iş kolları, konuya ilişkin bilgi seviyeleri ve görevlerini gerçekleştirdikleri alanların içeriği farklılık göstereceğinden, farklı sektörde insan kaynaklarından sorumlu olan kişilerin çalışma grubunda yer almasına dikkat edilmiştir. Katılımcılarla görüşmeler gerçekleştirilirken, araştırma konusunda bilgi sahibi olduklarını düşündükleri yeni katılımcılara yönlendirmeleri rica edilmiş, yeni katılımcıların araştırmada yer almayı kabul etmeleriyle de çalışma grubu içerisine eklenmişlerdir. Toplamda çalışma grubu içerisinde 51 katılımc bulunmaktadır. Her bir katılımcı " $\mathrm{K}$ " harfi ile kodlanmıştır ve kodunun yanına da sayı numarası eklenmiştir. Katılımcılara yönelik bilgiler, Tablo 1'de verilmektedir. 
Covid-19 Salgın Hastalık Sürecinin İşletmelerin İnsan Kaynakları Yönetimi Uygulamaları

Üzerindeki Etkileri

Tablo 1. Katılımcilara Ait Bilgiler

\begin{tabular}{|c|c|c|c|c|}
\hline KatılımcıKodu & Sektör & Görevi & Cinsiyet & Şehir \\
\hline K1 & Turizm & İnsan Kaynakları Direktörü & Erkek & İstanbul \\
\hline K2 & E-Ticaret & $\begin{array}{l}\text { İnsan Kaynakları ve } \\
\text { Koordinasyon Müdürü }\end{array}$ & Kadın & Samsun \\
\hline K3 & Telekomünikasyon & İş Veren & Erkek & İzmir \\
\hline K4 & Turizm & Genel Müdür & Erkek & Gürcistan \\
\hline K5 & Proje Hizmetleri & İnsan Kaynakları Uzmanı & Kadın & Ankara \\
\hline K6 & Turizm & İnsan Kaynakları Müdürü & Erkek & Antalya \\
\hline K7 & $\begin{array}{l}\text { Ayakkabi/Giyim } \\
\text { Sektörü }\end{array}$ & İnsan Kaynakları Müdürü & Kadın & Şanliurfa \\
\hline K8 & $\begin{array}{l}\text { Ayakkabı/Giyim } \\
\text { Sektörü }\end{array}$ & İnsan Kaynakları Uzmanı & Erkek & Ankara \\
\hline K9 & Madencilik & İnsan Kaynakları Uzmanı & Erkek & Ankara \\
\hline K10 & İnşaat Seramik & İnsan Kaynakları Müdürü & Kadın & Kütahya \\
\hline K11 & Turizm & İnsan Kaynakları Müdürü & Erkek & Aydın \\
\hline K12 & $\begin{array}{l}\text { İklimlendirme } \\
\text { /Makine }\end{array}$ & İnsan Kaynakları Müdürü & Kadın & İstanbul \\
\hline K13 & Gıda Sektörü & İnsan Kaynakları Müdürü & Erkek & Ankara \\
\hline K14 & Turizm & İnsan Kaynakları Müdürü & Erkek & Ankara \\
\hline K15 & Gida Sektörü & İnsan Kaynakları Müdürü & Kadın & Ankara \\
\hline K16 & Gıda Sektörü & İnsan Kaynakları Müdürü & Kadın & Aydın \\
\hline K17 & Enerji & İnsan Kaynakları Uzmanı & Kadın & Ankara \\
\hline K18 & Turizm & İnsan Kaynakları Müdürü & Kadın & Ankara \\
\hline K19 & Gayrimenkul & Genel Müdür & Erkek & İstanbul \\
\hline K20 & $\begin{array}{l}\text { İnsan Kaynakları } \\
\text { Danışmanlık }\end{array}$ & İnsan Kaynakları Uzmanı & Erkek & Ankara \\
\hline K21 & Giyim Sektörü & İnsan Kaynakları Uzmanı & Erkek & Aydın \\
\hline K22 & Oyuncak & İnsan Kaynakları Uzmanı & Erkek & İstanbul \\
\hline K23 & Eğitim & İnsan Kaynakları Müdürü & Kadın & Ankara \\
\hline K24 & Gida Sektörü & İnsan Kaynakları Müdürü & Erkek & Afyon \\
\hline K25 & İnşaat İmalat & İnsan Kaynakları Müdürü & Kadın & Eskişehir \\
\hline K26 & İçecek Sektörü & İnsan Kaynakları Müdürü & Kadın & İstanbul \\
\hline K27 & Turizm & İnsan Kaynakları Uzmanı & Kadın & Ankara \\
\hline K28 & Turizm & İnsan Kaynakları Müdürü & Kadın & Ankara \\
\hline K29 & Telekomünikasyon & İnsan Kaynakları Müdür Yardımcısı & Erkek & Ankara \\
\hline K30 & $\begin{array}{l}\text { İnşaat/Çimento } \\
\text { Sektörü }\end{array}$ & İnsan Kaynakları Uzmanı & Erkek & Ordu \\
\hline K31 & Turizm & İnsan Kaynakları Uzmanı & Kadın & Ankara \\
\hline K32 & Sanayi Sektörü & İnsan Kaynakları Müdürü & Erkek & Ankara \\
\hline K33 & Güvenlik Sektörü & İnsan Kaynakları Müdürü & Erkek & Ankara \\
\hline K34 & Sağlik & $\begin{array}{l}\text { İnsan Kaynakları ve Organizasyonel } \\
\text { Gelişim Direktörü }\end{array}$ & Kadın & Ankara \\
\hline K35 & Turizm & İnsan Kaynakları Uzmanı & Erkek & Ankara \\
\hline K36 & İnşaat & İnsan Kaynakları Müdürü & Erkek & Samsun \\
\hline K37 & Turizm & İnsan Kaynakları Müdürü & Erkek & Ankara \\
\hline K38 & $\begin{array}{l}\text { Tanıtım } \\
\text { (Hizmet Sektörü) }\end{array}$ & İnsan Kaynakları Uzmanı & Kadın & Ankara \\
\hline
\end{tabular}




\begin{tabular}{lllll}
\hline K39 & İnşaat & İnsan Kaynakları Uzamı & Kadın & Ankara \\
\hline K40 & $\begin{array}{l}\text { Endüstriyel } \\
\text { Ürünler }\end{array}$ & İnsan Kaynakları Müdürü & Erkek & Ankara \\
\hline K41 & Turizm & İnsan Kaynakları Uzmanı & Kadın & Kocaeli \\
\hline K42 & Ambalaj Üretimi & İnsan Kaynakları Uzmanı & Kadın & Mersin \\
\hline K43 & Turizm & İnsan Kaynakları Uzmanı & Erkek & İzmir \\
\hline K44 & İnşaat & İnsan Kaynakları Uzmanı & Erkek & Kocaeli \\
\hline K45 & Turizm & Genel Müdür & Erkek & Afyon \\
\hline K46 & Otomotiv & İnsan Kaynakları Uzmanı & Erkek & Ankara \\
\hline K47 & Turizm & İnsan Kaynakları Eğitim Sorumlusu & Kadın & Ankara \\
\hline K48 & İnsan Kaynakları & Uluslararası İse Alım Direktörü & Kadın & Aydın \\
& Danışmanlı̆̆1 & & & \\
\hline K49 & Metal Sektörü & İnsan Kaynakları Uzmanı & Kadın & Kayseri \\
\hline K50 & Hizmet Alımı & İnsan Kaynakları Müdürü & Erkek & Ankara \\
\hline K51 & Turizm & İnsan Kaynakları Müdürü & Kadın & Aydın \\
\hline
\end{tabular}

\section{Veri Toplama Aracı}

Araştırma sürecinde veri toplama aracı olarak, yarı yapılandırılmış görüşme tekniğinden yararlanılmıştır. Yarı yapılandırılmış görüşme sorularının belirlenmesinde; literatürde yer alan kavramlar ile mevcut durumda karşılaşılabilecek kavramlar ve bilgilerden yararlanılmıştır. Araştırma sorularının belirlenmesi ve oluşturulmasında karşılaştırmalı sonuçların yapılabilmesine olanak sağlayacak, soruların olmasına dikkat edilmiştir.

Araştırmacılar soruların hazırlanması sürecinde; soruların çok yönlü olmamasına, rahatlıkla anlaşılabilir yapıda olmasına, soruları cevaplayacak katılımcıları yönlendirici şekilde olmamasına ve soruların katılımcılar tarafından yorumlanabilecek şekilde olması gibi kurallara riayet etmiştir. Araştırmacılar tarafından hazırlanan görüşme formunun, çalışmanın amacına ne denli hizmet ettiğinin, anlaşılabilirliğinin ve uygulanabilirliğinin belirlenmesi amacıyla, konu ve kullanılan teknikle ilgili uzmanların görüşleri alınmıştır. Uzmanlardan gelen geri dönüşlere göre de görüşme soruları, revize edilmiştir. Araştırmada kullanılacak olan yarı yapılandırılmış görüşme soruları, Bursa Uludağ Üniversitesi Etik Komisyonu'na sunulmuş ve ilgili komisyon tarafından, görüşme soruları uygun bulunmuş ve katılımcılara uygulanmıştir.

Çalışmada, çeşitli sektördeki insan kaynakları yöneticileri ve sorumluları, uzman derlemesi, katılımcı onayı ve gerçekleştirilen görüşmelerin uzun za- 
man aralığında gerçekleştirilmesine bağlı olarak, elde edilen bilgilerin inandırıcılığının yani iç geçerliliğinin ve konuyla alakalı doğru ve geçerli bilgilerden oluşması amaçlanmıştır. Çalışmada elde edilen verilerin inandırıcılığı ve güvenirliğini test etmek ve etik kurallar dahilinde yükseltmek gayesiyle, sağlanan bilgilerin tutarlılığı da sürekli olarak denetlenmiştir. İlgili doğrultuda elde edilen bulguların, görüşme sorularının oluşturulması aşamasında kullanılan kavramlar ve bilgilerle eşteşliği de denetlenmiştir (Tuna ve diğerleri, 2018, s. 374).

Çalışmanın dış geçerliliği yani tutarlığının sağlanması amacıyla katılımcılardan alınan bilgiler olduğu gibi aktarılmış ve araştırmacıların kendi görüşleri dikkate alınmamıştır. Araştırmada sağlanan verilerin tutarlığı ile ilgili olarak, çalışmayı gerçekleştiren araştırmacilar ve nitel araştırma konusunda uzmanlaşmış bir öğretim üyesi ayrı ayrı kodlamalarda bulunmuş ve gerçekleştirilen kodlamalar karşılaştırılmıştır. Çalışmanın dış güvenirliğini - kontrol edilebilirliğini - sağlamlaştırmak amacıyla araştırmayı oluşturan konuyla ilgili ön deneyimleri, çalışma alanı, bulundukları yer, araştırmanın gerçekleştirildiği sosyal alan ile araştırmanın veri kaynağı olan katılımcılar, araştırmada sağlanan veriler kavramsal dizin ve analiz yöntemleriyle ilgili ayrıntılı bilgilere de yer verilmiştir.

\section{Verilerin Toplanma Süreci}

Katılımcıların hem kendilerini hem de konuyla ilgili görüşlerini rahat ve açık bir şekilde bildirebilmelerini sağlamak amacıyla, katılımcıların uygun gördükleri randevu günü ve saatinde, ses kaydının alınmasına müsait dijital platformlarda (Zoom, Facetime), araştırmanın verileri toplanmıştır. Görüşmeler gerçekleştirilirken sağlıklı ve doğru bilgilerin temin edilebilmesini sağlayabilmek amacıyla, her katılımcıya sorular, aynı anlamı sağlayacak şekilde ve aynı kelimelerin kullanılması ve aynı tonlama ile yöneltilmiştir. Gerçekleştirilen görüşmeler, tek kişi tarafından yapılmıştır. Ancak herhangi bir veri kaybı olmaması adına ses kaydı ve not alma teknikleri bir arada kullanılmıştır. Ses kaydı ve not alma sürecinde, her soruya karşlık gelen bilgiler, ilgili alanlara yazılarak elde edilmiştir. Katılımcılardan sağlanan verilerin çözümlenmesi aşamasında, 203 sayfalık veri elde edilmiştir. Katılımcılardan sağlanan verilerin sınanmasında, yazıya aktarılan bilgilerden oluşan dokümanlar- 
dan yararlanılmıştır. Araştırma kapsamında belirlenen temalara karşlık gelen veriler işlenmiştir. Katılımcılardan alınan bilgilere doğrudan alıntılamalarda bulunarak, bulguların yorumlanması sağlanmıştır.

\section{Verilerin Analizi}

Araştırma sürecinde sağlanan verilerin analizi sırasında; içerik analizi ve betimsel analiz teknikleri kullanılmıştır. Betimsel analiz; araştırmacıların, katılımcılardan elde ettikleri verileri, belirlenen temalara göre özetleyerek objektif olarak yorumladığı, katılımcılar tarafından belirtilen fikir ve görüşleri açık olarak yansıtabilmek adına, doğrudan alıntılamalarla sürekli olarak yer verildiği, araştırmadan sağlanan bulguların neden-sonuç ilişkisiyle yorumlandığı bir analiz tekniğidir. Verilerin ortaya konması aşamasında, açıklayıcllık, farklı görüşs, çeşitlilik, temaya uygunluk ile uç örnekler gibi ilkeler dikkate alınmaktadır (Altunay, Oral ve Yalçınkaya, 2014: 67). Tablo 2' de COVID19 kapsamında insan kaynakları yönetimi ile ilgili tema ve alt temalara yönelik bilgilere yer verilmektedir.

Tablo 2. COVID-19 Kapsamında İnsan Kaynakları Yönetimi ile İlgili Tema ve Alt Temalar

\begin{tabular}{l}
\hline 1. İşletmelerin Mevcut İKY Uygulamaları ve COVID-19'un Etkileri \\
\hline 1.1. Nitelikli iş gücü ve alanında yetkin personelinizi elinizde tutmak için uygulamakta olduğunuz ve uy- \\
gulayacağını politikalar \\
1.2. Mevcut dönemde personel temini için hangi kanalların (gazete ilanları, referans-eş-dost tavsiyesi, eği- \\
tim kurumları tavsiyesi, internet siteleri, sosyal medya vb) kullanılacağı \\
1.3. Mevcut dönemde personel seçiminde hangi yöntemlerin (test, mülakat, sağlık raporu vb) uygulandığı \\
ve COVID-19'un bu konuda değişiklere neden olup olmayacağı \\
1.4. Mevcut dönemde personel eğitiminde hangi yöntemlerin uygulandığı ve COVID-19'un bu konuda \\
değişiklere neden olup olmayacağı \\
1.5. Personelin motivasyonunu arttırmak için gerçekleştirilen uygulamalar ve COVID-19'un ilgili uygula- \\
malara etkisi \\
1.6. Mevcut performans değerlendirme kriterleri ve COVID-19'un meydana getireceği değişiklikler \\
2. COVID-19'un İş Planlaması ve Faaliyetlerine Etkisi \\
\hline 2.1. COVID-19 sürecinde sağlık ve güvenlik açısından, evden çalışma gibi çalışma programlarının destek- \\
lenmesi ve çalışanlarla olan iletişimin, yaygın bir şekilde internet üzerinden gerçekleştirilmesi \\
2.2. COVID-19 sürecinde çalışanların iş tanımlarında veya iş gerekliliklerinde bir değişim olması \\
2.3. COVID-19 sürecinde insan kaynakları planlamasını yaparken ihtiyaç duyulacak personel sayısı \\
2.4. COVID-19 sürecinde bir işletmede yapılan farklı işlerin göreceli değerlerinde bir farklılaşma olması \\
\hline 3. COVID-19'un Kariyer Planlaması, Ücret, İş Güvenliği ve İ Değerlendirmesi Üzerindeki Etkileri \\
\hline 3.1. COVID-19 sürecinde çalışanların kariyer planlanmalarında, insan kaynakları biriminin gerçekleştire- \\
bileceği farklılıklar \\
3.2. COVID-19 sürecinde personele ödenen ücretlerde bir farklılaşma olabilmesi \\
3.3. COVID-19 sürecinde iş güvenliği ve çalışan sağlığı konusunda bir farklılaşma olması \\
3.4. COVID-19 sürecinde iş güvencesi konusunda bir farklılaşma olması \\
\hline
\end{tabular}


4. COVID-19'un Dış Kaynak Kullanımı, Kullanılan Teknoloji ve Yabancı Uyruklu Personel İstihdamına Etkisi

4.1. İşletmenin ilerleyen dönemlerde dış kaynak kullanımı (outsourcing) politikalarının ne yönde olacağı ve COVID-19' un bu sürece etkisi

4.2. COVID-19 sürecinde insan kaynaklarında teknoloji kullanımında bir farklılaşma olması

4.3. COVID-19 sürecinde yabancı personel çalş̧ırma ve uluslararası insan kaynakları piyasasında değişiklikler olması

Tablo 2'de görüldüğü gibi araştırmada elde edilen verilere göre tema ve alt temaların oluşturulması sürecinde tüm dökümler ayrı ayrı okunmuş ve yine birbirinden bağımsız olarak alt temaları oluşturmuştur. Daha sonra araştırmacılar tarafından, verilerin altı alt tema altında toplanması konusunda uzlaşmaya varılmıştır.

\section{Bulgular}

Araştırma sürecinde gerçekleştirilen gözlem, görüşme ve ses kayıtları, Microsoft Office Word 2013 paket programinda, orijinal haliyle yazıya aktarılmıştır. Araştırmacılar tarafından ayrı ayrı, defalarca okunduktan sonra gerekli kodlama işlemleri yapılmıştır. Gerçekleștirilen kodlama işleminden sonra, oluşturulan kodlar bir araya getirilmiş ve ortak yönleri belirlenmiştir. İlgili işlemlerin devamında araştırma konusuna göre, bulguların temelini oluşturan temalar ve temalara bağlı alt temalar belirlenmiştir. Konuyla ilgili uzmanların görüşlerine göre, kod listeleri ile temaların son hali oluşturulmuştur. Son halini alan görüşme formunun güvenilirliğini ve geçerliğini sağlamak amaciyla son bir kez alanında yetkin öğretim üyesine tekrar okutulmuş ve kodlanmıștır.

Gerçekleştirilen kodlamalar ile görüşme sürecinde elde edilen kodlamalar karşılaştırılmış ve birbirleriyle uyumlu olduğu sonucuna ulaşılmıştır. Verilen bilgilerden gerçekleştirilen kodlama ve temaların güvenirliği sağladığı konusunda araştırmacilar hem fikir olmuştur. Tablo 3'te konuya ilişkin yetkin kişilerle yapılan görüşmeler neticesinde, COVID-19 kapsamında insan kaynakları yönetimi ile ilgili tema ve alt temalara yönelik bulgulara yer verilmektedir. Katılımcılar ilgili tema ve alt temalara birden fazla cevap verme hakkına sahip olduklarından bu, ilgili kodlama ve kodlama sıklığına eklenmiştir. 
Tablo 3. COVID-19 Kapsammia İnsan Kaynaklar Yönetimi İle İlgili Tema ve Alt Temaların Katılımcılara Göre Dă̆ılımı

\begin{tabular}{|c|c|c|}
\hline $\begin{array}{l}\text { Temalar ve Alt Temalara Göre Kodlamalar } \\
\text { Listesi }\end{array}$ & $\begin{array}{l}\text { Kodlanma } \\
\text { düzeyi }\end{array}$ & $\begin{array}{l}\text { Toplam Kodlanma } \\
\text { Düzeyi }\end{array}$ \\
\hline \multicolumn{3}{|l|}{ İşletmelerin Mevcut İKY Uygulamaları ve COVID-19'un Etkileri } \\
\hline $\begin{array}{l}\text { Nitelikli iş gücü ve alanında yetkin personelinizi elinizde tutmak } \\
\text { için uygulamakta olduğunuz ve uygulayacağınız politikalar }\end{array}$ & 89 & \multirow[t]{6}{*}{614} \\
\hline $\begin{array}{l}\text { Mevcut dönemde personel temini için hangi kanallarının (gazete } \\
\text { ilanları, referans-eş-dost tavsiyesi) eğitim kurumları tavsiyesi, inter- } \\
\text { net siteleri, sosyal medya vb) kullanılacağı }\end{array}$ & 123 & \\
\hline $\begin{array}{l}\text { Mevcut dönemde personel seçiminde hangi yöntemlerin (test, mü- } \\
\text { lakat, sağlık raporu vb) uygulandığı ve COVID-19'un bu konuda } \\
\text { değişiklere neden olup olmayacağı }\end{array}$ & 119 & \\
\hline $\begin{array}{l}\text { Mevcut dönemde personel eğitiminde hangi yöntemlerin uygulan- } \\
\text { dığı ve COVID-19'un bu konuda değişiklere neden olup olmayacağı }\end{array}$ & 73 & \\
\hline $\begin{array}{l}\text { Personelin motivasyonunu arttırmak için gerçekleştirilen uygula- } \\
\text { malar ve COVID-19'un ilgili uygulamalara etkisi }\end{array}$ & 146 & \\
\hline $\begin{array}{l}\text { Mevcut performans değerlendirme kriterleri ve COVID-19'un } \\
\text { meydana getireceği değişiklikler }\end{array}$ & 64 & \\
\hline \multicolumn{3}{|l|}{ COVID-19'un İş Planlaması ve Faaliyetlerine Etkisi } \\
\hline $\begin{array}{l}\text { COVID-19 sürecinde sağlık ve güvenlik açısından, evden çalışma } \\
\text { gibi çalışma programlarının desteklenmesi ve çalışanlarla olan ile- } \\
\text { tişimin yaygın bir şekilde internet üzerinden gerçekleştirilmesi }\end{array}$ & 53 & \multirow[t]{4}{*}{206} \\
\hline $\begin{array}{l}\text { COVID-19 sürecinde çalışanların iş tanımlarında veya iş gereklilik- } \\
\text { lerinde bir değişim olması }\end{array}$ & 51 & \\
\hline $\begin{array}{l}\text { COVID-19 sürecinde insan kaynakları planlamasını yaparken ihti- } \\
\text { yaç duyulacak personel sayısı }\end{array}$ & 51 & \\
\hline $\begin{array}{l}\text { COVID-19 sürecinde bir işletmede yapılan farklı işlerin göreceli de- } \\
\text { ğerlerinde bir farklılaşma olması }\end{array}$ & 51 & \\
\hline \multicolumn{3}{|l|}{$\begin{array}{l}\text { COVID-19'un Kariyer Planlaması, Ücret, İş Güvenliği ve İş Değer- } \\
\text { lendirmesi Üzerindeki Etkileri }\end{array}$} \\
\hline $\begin{array}{l}\text { COVID-19 sürecinde çalışanların kariyer planlanmalarında, insan } \\
\text { kaynakları biriminin gerçekleştirebileceği farklılıklar }\end{array}$ & 79 & \multirow[t]{4}{*}{333} \\
\hline $\begin{array}{l}\text { COVID-19 sürecinde çalışanlara ödenen ücretlerde bir farklılaşma } \\
\text { olabilmesi }\end{array}$ & 55 & \\
\hline $\begin{array}{l}\text { COVID-19 sürecinde iş güvenliği ve çalışan sağlı̆̆ı konusunda bir } \\
\text { farklılaşma olması }\end{array}$ & 142 & \\
\hline COVID-19 sürecinde iş güvencesi konusunda bir farklılaşma olması & 57 & \\
\hline \multicolumn{3}{|l|}{$\begin{array}{l}\text { COVID-19'un Dış Kaynak Kullanımı, Kullanılan Teknoloji ve Ya- } \\
\text { bancı Uyruklu Personel İstihdamına Etkisi }\end{array}$} \\
\hline $\begin{array}{l}\text { İşletmenin ilerleyen dönemlerde dış kaynak kullanımı (outsour- } \\
\text { cing) politikalarının ne yönde olacağ ve COVID-19'un bu sürece } \\
\text { etkisi }\end{array}$ & 95 & \multirow[t]{3}{*}{264} \\
\hline $\begin{array}{l}\text { COVID-19 sürecinde insan kaynaklarında teknoloji kullanımında } \\
\text { bir farklılaşma olması }\end{array}$ & 100 & \\
\hline $\begin{array}{l}\text { COVID-19 sürecinde yabancı personel çalıştırma ve uluslararası in- } \\
\text { san kaynakları piyasasında değişiklikler olması }\end{array}$ & 51 & \\
\hline
\end{tabular}


Tablo 3'te, “İşletmelerin Mevcut İKY Uygulamaları ve COVID-19'un Etkileri" temasına verilen cevaplar incelendiğinde, "Nitelikli iş gücü ve alanında yetkin personelinizi elinizde tutmak için uygulamakta olduğunuz ve uygulayacağınız politikalar" alt temasına verilen cevaplar tekrarlanma sıkılığına göre şu şekildedir: "Alanında yetkin ve başarll personel önemsemek, aidiyeti arttormak, çalışanlarm güvenliliğini mutluluğunu ve motivasyonunu sağlamak, eğitimler vererek takım ruhu ve bilinci oluşturmak, iyi bir ücret imkanı sunmak, sosyal etkinlikler düzenlemek ve yıl sonunda ödüllendirilmektir" (K1, K2, K3, K4, K5, K7, K9, K10, K11, K14, K15, K16, K19, K21, K22, K25, K26, K27, K28, K30, K31, $\mathrm{K} 33, \mathrm{~K} 34, \mathrm{~K} 35, \mathrm{~K} 40, \mathrm{~K} 42, \mathrm{~K} 46, \mathrm{~K} 49$ ve K50), "virüs bulaşma riskini kaldıracak önemler ve online eğitimler uygulanmaktadır" (K1, K8, K9, K14, K32, K35, K41, $\mathrm{K} 44, \mathrm{~K} 45)$, "eğitim sistemi ve yetenek yönetimi ile yönetici aday programı kullamılmaktadır" (K12, K16, K17 ve K20), "online eğitimler ve Webinar kullanılmaktadır" (K9, K18, K39, ve K47), “tüm personele kısa çalışma ödeneği ve ücretsiz izin alamayanlara maddi destek să̆lanmaktadır" (K1, K13, K38, K43), "eksiksiz olarak çahı̧anlara maaş ödenmektedir" (K1, K3, K6, K23), "adil ve şeffaf bir yönetim anlayışı uygulanmaktadır (K31 ve K42), IŞKUR ve işsizlik fonundan yararlanılmaktadır " (K37 ve K44), "personele prim desteği de sağlanmaktadır" (K3 ve K36), "performans değerlendirme sistemi ve açık iletişim sistemi kullanılmaktadır" (K5), "esnek çalışma saatleri uygulanmaktadır" (K8), "aldiklar ücretlere ilave olarak; yakacak-bayram ikramiyeleri- Ramazan erzak paketleri- her ay düzenli yapılan motivasyon çekilişleriher yıl düzenli olarak yapllan geleneksel piknikler- sürpriz happy hour etkinlikleriyılbaşı gala programlart- iftar programları- sürpriz yemekler- sinema organizasyonları- programlarımızla tüm çalışanlarımıza eşitlikçi uygulamalar bulunmaktadır (K10), motivasyonu düşüren etmenler belirlenmektedir" (K11), "Çocukları için indirimli okutma, ulaşım, yemek, sosyal - spor tesislerinden yararlanma imkanları bă̆layıcılığı arttıran politikalar uygulanmaktadır (K23), iş rotasyonu ve işe alıştırma uygulamaları" (K24), "yurtdışı eğitimleri personel üzerinde olumlu etki yaratmaktadır" (K29), "çalışma süresi düşürülebilir ve mola süreleri arttırlabilir" (K32), "sürekli gelişim programları uygulanmaktadır" (K34), "65 yaş üstü personel izne çıkarılmıştır (K44), karşılıklı saygı ve güven ortamının să̆lanması" (K46), "işten çıkarma yerine ücret düşüklüğüne gidilmeli (K48), ve işten çıkarmalarda bulunulmuş ve kalan personele ücretleri ödenmektedir" (K51). K1, K3, K4, K18, K21, K22, K23, K26, K31 ve K38 konuyla ilgili olarak; “Böylece tüm personelimizi elimizde tutmak kolaylaşacaktır. Tabi moral, motivasyon aktiviteleri sürekli devam edecektir" şeklinde görüşlerini bildirmiştir. Alt temayla ilgili olarak K6 ve 
K14; "Video konferanslar ile çalışanların morali yüksek tutulmaya çalışılarak salgın sonrası yapılacaklar hakkında fikir alş̧erişinde bulunabiliyoruz. COVID-19 ile birlikte hizmet sektöründe çalışacak personel daha değerli hale gelmiştir. Eğitim düzeyi yüksek, bilinçli, hijyen koşullarna dikkat edecek personele ihtiyaç duyulmaktadır." şeklinde ifade vermiştir. İlgili tema ile ilgili K39: "Proje sayılarımız fazladır. Sahra Hastaneleri yaptığımı için, iş gücümüz ve personel sayı isteğimiz artmış bulunmakta. Sahip olduğumuz personel aktif halde şuan çalışıyor. Yapmış olduğumuz çalışmalar personellerimizi maddi ve manevi açıdan olumlu etkilediği için politikalarımızda değişiklik görmüyoruz" şeklinde görüş bildirmiştir. Konuyla ilgili K50; "Tüm şirketler, en iyi yetenekleri ve özel becerilere sahip liderleri işe almak ister. Bu çalışanlar elde tutmak da şirketlerin önceliklerinden biridir. İyi performans gösteren ve yüksek yetkinlikteki çalş̧anların şirketle bağlantılarmın uzun soluklu olması, bu çalışanlarm motivasyonunun doğru biçimde sağlanmast ile mümkün olacaktır." şeklinde görüş bildirmiştir. Araştırmada elde edilen bulgular incelendiğinde, insan kaynakları yöneticilerinin, çalışanların örgütsel aidiyetini, motivasyon ve sosyal aktivitelerle yükseltmeye çalıştığı, eğitim uygulamalarına ağırlık verdikleri, online iletişim sistemlerinden yararlandıkları, COVID-19 sürecinde çalışanların ücretlerini ödedikleri, devletin bu süreçte sağladığı imkanlardan yararlanarak, iş görenleri örgütte tutma gayreti içerisinde oldukları söylenebilir.

"Mevcut dönemde personel temini için hangi kanalların (gazete ilanları, referans-eş-dost tavsiyesi, eğitim kurumları tavsiyesi, internet siteleri, sosyal medya vb) kullanıldığı" alt temasıyla ilgili olarak katılımcılardan alınan cevaplar, tekrarlanma sıklığına göre şu şekildedir: "Kariyer.net" (K2, K5, K8, K9, $\mathrm{K} 15, \mathrm{~K} 22, \mathrm{~K} 26, \mathrm{~K} 29, \mathrm{~K} 33, \mathrm{~K} 39, \mathrm{~K} 41, \mathrm{~K} 42$, K43, K46, K47 ve K48), "internet işe alm siteleri" (K12, K16, K17, K19, K27, K28, K30, K34, K40, K44, K47, K49, K50 ve K51), "referans eş-dost tavsiyeleri" (K3, K6, K16, K19, K22, K27, K34, K35, K36, K38, K40, K41 ve K49), "internet” (K6, K7, K10, K11, K13, K20, K21, K25, K26, K37, K38 ve K43), "sosyal medya “(K3, K15, K16, K18, K20, K23, K24, K26, $\mathrm{K} 28$, K34, K43 ve K47), İ̧SUR (K2, K6, K10, K23, K24, K30, K32, K36, K40, K44), "Linkedin" (K5, K9, K22, K29, K33, K39, K43, K47 ve K48), “üniversite tavsiyeleri" (K13, K18, K26, K28, K29, K34, K40, K42 ve K50), "kendi internet sitemizi kullanıyoruz" (K5, K9, K15, K17, K18, K23, K35 ve K39), “işe alım danışmanlık firmaları" (K12, K14, K16 ve K25), "belirttiğiniz tüm yöntemleri kullanmaktayı" (K1, K4, K31 ve K45), K1, K4, K31 ve K45), "gazete" (K18 ve K38), 
"Skype" (K21), "Hangouts" (K21), "Meet" (K21), "Gel Başla" (K5), "Bilkent Mezunlar Sayfasi" (K5), "Proje Fonlar internet sitesi" (K5)'dir. COVID-19'dan sonra personel temini kanalını değiştireceğini ifade eden katılımcllar (K1, K3, K9, K10, K11, K21, K23 ve K36) iken diğer tüm katılımclar ayn kanallar ile personel teminine devam edeceğini belirtmiştir. Alt temayla ilgili olarak, K20, K34 ve K45: "Gazete artık kullanılmayan bir kanal sadece mavi yakalı işgören bulmada etkili oluyor." şeklinde görüş bildirmiştir. K11 ve K21 ise "Biz kendi işletmemiz adına yüz yüze yapılan her başขuruyu daha yararl bulmaktayız. Başむuran personel adayının dış görünümünü, konuşma tarzın daha iyi gözlemleyebiliyoruz. Fakat COVID-19 süreci neticesinde internet sitelerinden yararlanmayı planliyoruz. Bize özgeçmiş formlarm gönderen personel adaylarmdan ön eleme yaparak as kadroyu oluşturma planındayız." demiştir. K23 de konuyla ilgili olarak, "IŞSUR'u engelli personel bulmak için kullanıyoruz. Ancak personel seçimi için fiziki ortamlarda uygulama ve seçme sinavlarn gerçekleştirilememiş, ertelenmiş ve halen uygulanamamıştır. İlerki tarihlerde elektronik seçme sınavları vb uygulamalar düşünülebilir." şeklinde fikrini ifade etmiştir. K28 ise İKY' de iş gören temini ile ilgili olarak, "Kısa vadede işletmenin faaliyetlerini aksatmadan sürdürülebilmesi için gerekli personelin temin edilmesi insan kaynakları planlamasını öncelikli hedeflerindendir. Gelecek dönemlerde işletmenin yatırım veya benzeri değişiklikler sonucunda geleceği seviyedeki personel ihtiyaçlarmm temin edilmesi insan kaynaklar planlamasının hedefleri içerisinde yer alır." ifadesiyle görüşünü belirtmiştir. Alt temadan elde edilen bulgular ışığında, katılımcların büyük bir çoğunluğu COVID-19 süreci öncesi ve sonrasında online olarak iş gören temininde bulunduğu ve ilgili sistemleri kullanmaya devam edeceği söylenebilir. Teknolojik gelişmelerin, IKKY alanında yaygın olarak kullanılması hem çok sayıda adaya ulaşılmasını mümkün kılmakta, hem de sağlık ve güvenlik açısından da son derece önem taşımaktadır.

"Mevcut dönemde personel seçiminde hangi yöntemlerin (test, mülakat, sağlık raporu vb) uygulandığı ve COVID-19'un bu konuda değişiklere neden olup olmayacağı" alt temasıyla ilgili olarak katılımclardan sıklıkla alınan ifadeler şu şekildedir: "Genel, beceri, açık uçlu testler, tecrübe testleri" (K3, K7, K8, K9, K11, K12, K13, K14, K16, K18, K20, K21, K23, K24, K26, K27, K29, K30, K33, K34, K36, K40, K42, K47, K48 ve K50), "sağ lı raporu” (K3, K4, K7, K8, K9, K16, K17, K21, K25, K30, K31,K38, K41, K42, K45, K46, K47, K48 ve K49), "online mülakat” (K1, K5, K7, K9, K10, K11, K15, K16, K18, K26, K34 ve K39), "yabancı dil testleri" (K9, K12, K17, K18 K22, K23, K25, K30, K33, ve K47), "kişilik 
envanteri" (K9, K12, K16, K17, K20, K30 ve K34), "işletmenin hekiminden rapor alryoruz" (K2, K13, K17, K27, K32 ve K44), "kronik rahatsizlik testleri" (K13, K14, $\mathrm{K} 24$ ve K50), "adli sicil kaydı" (K3, K4 ve K7), "referanslarm kontrol edilmesi" (K7, K21 ve K43), “COVID-19 testi isteyeceğiz” (K2, K3 ve K14), “telefon ile mülakat" (K6 ve K30), "belirttiğiniz tüm teknikleri uyguluyoruz" (K2), "sağllk ve hijyen konusunda bilgi testleri" (K14), "vaka analizi" (K17), "kişilik testi" (K18), "önceki işinden ayrilma nedeni" (K24) ve "sertifika" (K40)'dır. Alt temayla ilgili olarak, K12: "Uzun vadede insanm yerine yapay zekâ robotlarm personel seçimi konusunda etkin rol alacakların düşünüyorum" diyerek ilerleyen dönemde iş hayatında dijital personel olabileceğini ifade etmiştir. K23: "COVID-19 nedeniyle Mart ayında yapllacak test ve yazll sinavlar gerçekleştirilememiş ve ileriki bir tarihe ertelenmiştir. Sürecin devam etmesi durumunda daha sıkı tedbirler alınarak aynı uygulamanın yürütülmesi, tümünün ayn günde değil aralıkl günlerde yapılması gibi farklllaşabileceği düşünülmektedir." Şeklinde görüşünü bildirmiştir. K27 ve K35: "Mülakatlarda artık kişilerin kişisel verilerini koruma kanunu diye bir düzenleme gelmiştir. Sağlık raporu istenememektedir. Artık kişilerin özel verilerini öğrenemiyorsunuz. Örneğin kan grubu gibi” şeklinde görüş bildirmiştir. K38: “COVID-19 ile ilgili olarak herhangibir testten geçirmeyi düşünmüyoruz. Nihayetinde bugün test sonucu negatif çıkan bir personel iki gün sonra pozitif olarak şirkete gelip personelin arasına karışabilir ve bunu işe alımlarla kontrol edemeyiz. İş sağhlğı ve güvenliği kontrollerinin de başlangıç için yeterli olabileceğini düşünüyoruz." demiştir. K46' da ilgili konu da "Personel seçiminde genellikle mülakat ve davranışsal uygunluk testi yöntemlerini uyguluyoruz. COVID-19 sürecinde ise bu yöntemler internet üzerinden yapılarak farklılaşmaya gidebilir. Sağglk raporu ve test cevaplarmı adaylarımıdan mail yoluyla tarafimiza gönderme talebinde bulunabiliriz. Bu sayede personel adaylarının işletmemize risk taşımadan başvuru yapabileceğini düşünüyorum" diyerek görüşünü bildirmiştir. Araştırmadan elde edilen bulgulara göre kattlımcıların geneli artık klasik yöntemlerden ziyade teknolojik iletişim araçlarının, ilerleyen dönemlerde daha yaygın olacağını ve COVID-19 sürecinden sonra mutlaka yaygın olması gerektiğini ifade etmektedir. İlgili alt temadan elde edilen bilgilere göre, özellikle COVID-19 ile personel seçiminde dijital platformlar hem sağlık hem de güvenlik açısından önem kazanmaktadır.

"Mevcut dönemde personel eğitiminde hangi yöntemlerin uygulandığ 1 ve COVID-19'un bu konuda değişiklere neden olup olmayacağı" alt temasıyla ilgili olarak alınan cevaplar tekrarlanma sıkılığına göre yandaki gibidir: "Kurumumuzda eğitimler, işe giriş, iş başı ve mevcut personele yönelik (iş sağhı̆̆ı ve 
güvenliği, sağlık, hijyen vb.) şekilde verilmektedir. Bu eğitimler uzaktan eğitimlerle de desteklenmektedir ve desteklenecektir. COVID-19 sürecinde hem virüs ile ilgili hem de sosyal mesafeye uygun olacak şekilde, küçük birimler halinde eğitimler verilmektedir ve verilmeye devam edilecektir" (K4, K5, K6, K7, K8, K10, K11, K12, K14, K15, K16, K17, K19, K21, K23, K24, K25, K27, K28, K30, K31, K32, K33, K34, K35, K36, K37, K38, K40, K41, K43, K44, K45, K46, K47, K49, K50 ve K51), “ELearning - Uzaktan Eğitim" (K1, K5, K9, K10, K12, K13, K15, K17, K18, K19, K22, K23, K26, K29, K30, K32, K34, K39, K42, K43, K47, K48 ve K49), "sertifikal eğitimler" (K4, K5 ve K13), "360 Etkinlik sistemi uygulamaktadır" (K9), "Koç Akademi" (K9), "liderlik gelişim programı" (K20), "yönetici yetiştirme programı" (K20), "sosyal medya" (K43), "usta öğreticilerle eğitim verilmektedir" (K7), "COVID-19 ile ilgili iş sağhlğı ve güvenliği eğitimi verilecek" (K6), "ihtiyaca göre eğitimler düzenlenmektedir" (K2) ve "yüzyüze eğitim yapllyordu, uzaktan eğitimle gerçekleştirilmektedir" (K3) şeklindedir. Alt temayla ilgili olarak, K1: "Uzaktan eğitim, içinde bulunduğumuz dönem dikkate alındı̆̆ında, yüzyüze eğitime göre daha güvenlidir." diyerek görüşünü ifade etmiştir. K4: "COVID-19 kapsamında farkındalık ve bilinçlendirme sağlayacak posterler, videolar vb. hazırlanarak personel panoları veya bilgilendirme ekranlarnda yaymlanmalıdır. Salgin süreci sonrasında personellerin acil durum yönetimini pekiştirmesi ve öğrenmesi amacı ile bilgisayar ve medya sistemleri aracılığı ile eğitimin arttırlmasını düşünüyoruz." şeklinde ifade bildirmiştir. K30: "Normal süreçte kurum içi Türkiye' de kullanlan en iyi dijitalleşme projesi olan "dijitaliKK" platformunda e-nocta üzerinden eğitimlerimiz takip edilmektedir. Online eğitimlerin dışında perculas sisteminden de canlı eğitimlere de başlanılmış durumdadır." şeklinde görüşünü bildirmiştir. K19: COVID-19 sürecinde tercihimizi online eğitimlerden yana kullanmayı düşünüyoruz. Bunun için hem bilgi sistemleri altyapımızı hazır hale getirmemiz, hem de online eğitim sağlayan doğru dış kaynakları belirlememiz gerekmektedir" demiştir. K37 ise "Şu an devletin ve odalarm bize PDF olarak atmıs oldukları önlemleri çalışanlarımıza uyguluyoruz ve her gün bu kuralları anlatıp bire bir eğitim veriyoruz. Ĕ̆ger bu süreç uzarsa sağlık kurumlarından kesin eğitim satın alma ihtiyacımı olacak." olduğunu belirtmiştir. K20 ise "Uzaktan eğitimin, yüzyüze eğitim kadar etkili olmayacă̆ın düşünüyorum." diyerek olumsuz görüş bildirmiştir. Alt temaya verilen cevaplar incelendiğinde, İKY yöneticilerinin personelleri için çeşitli eğitim sistemleri uyguladıkları ve özellikle içinde bulunduğumuz dönemde uzaktan eğitime yoğunlaştıklarını söylemek mümkündür. 
"Personelin motivasyonunu arttırmak için gerçekleştirilen uygulamalar ve COVID-19'un ilgili uygulamalara etkisi" alt temasıyla ilgili katılımclardan alınan cevaplar şu şekildedir: "doğum günleri" (K1, K9, K10, K12, K17, K22, $\mathrm{K} 28, \mathrm{~K} 31, \mathrm{~K} 35, \mathrm{~K} 40, \mathrm{~K} 45$ ve K47), "özel gün partileri ve hediyeleri (anneler günü, babalar günü, yılbaşı vs.)" (K1, K10, K12, K17, K22, K28, K31, K32, K33, K35, K40 ve K41), "eğitim seminerleri" (K1, K5, K6, K7, K8, K10, K29, K31 ve K39), "iftar ve akşam yemek organizasyonları" (K1, K10, K15, K17, K24, K32, K33, K47 ve K49), "sosyal etkinlikler" (K3, K19, K21, K29, K31, K43, K49 ve K51), "adil çalışma düzeni ve takdir sistemleri" (K2, K17, K19, K22, K23, K24, K28 ve K31), "happy hour'lar" (K1, K9, K10, K25, K27 ve K28), "psikolojik destek" (K7, K14, K20, K23, K34 ve K36), "personel aile etkinlikleri (23 Nisan vb.)” (K1, K10, K17, K31 ve K35), "arkadaşça bir çalışma ortamı" (K4, K18, K19, K46 ve K51), "prim verilmesi" (K3, K11, K17, K19 ve K36), "bonus sistemi" (K5, K6, K17 ve K19), "online görüşmeler-terapiler" (K30, K34, K35 ve K48), "outing'ler" (K1, K17, K25 ve K45), performans değerlendirme sistemleri (K5, K18, K37 ve K50), "takım buluşmaları ve çalışmaları" (K5, K17, K19 ve K20), "balolar" (K1, K10 ve K17), "partiler" (K1, K10, K17 ve K29), "spor aktiviteleri" (K1, K25 ve K17), "ortak kullantm alanlarmın hijyen ve temizliklerinin sağlanması" (K7, K14 ve K44), "sağhlkl rekabet ortamı" (K4, K18 ve K19), "yemekhane mönüsüne direnç kazandırıcı yiyeceklerin eklenmesi" (K13, K20 ve K26), "aym personeli" (K27 ve K41), "cherity aktiviteleri" (K1 ve K17), "evden çalışma imkanmm sunulması" (K16 ve K20), "kişisel kariyer" (K4 ve K18), "işini kaybetmeme garantisi verme" (K37 ve K38), "sağllk kiti (maske, eldiven, dezenfektan) dağıtımı" (K15 ve K42), "bayramlarda çikolata dağıtımı" (K15), "iş sağhlğı güvenliği uygulamaları" (K39), "OYAK Doktorum programı" (K30), "workshop" (K22), "Mayıs ayında 1 hafta boyunca Çalışanlara Teşekkür Haftası'nı kutluyoruz" (K18), "Sodexho" (K5), "fazladan izin kullandırma" (K11) ve "özel sağlık sigortası" (K5)'dır. Konuyla ilgili katılımcı görüşlerine bakıldığında ise K9, K12, K39, K40 ve K47: "Sosyalleşme süreçlerini online ortama taşıdık." şeklindedir. Katılımcllara göre moral yükseltici aktivitelerin tamamı COVID-19 sürecinde ertelenmektedir. K1, K3, K5, K45 ve K47 ilgili konuda: “Gerçekleştirilen aktiviteler, sosyal mesafe korunması koşulu ile devam edecektir. Zira, personelimizin motivasyona şimdi daha çok ihtiyacı mevcuttur." şeklinde görüş bildirmiştir. K13 ise "yemekhane düzeneği, servis düzeneği gibi tedbirlerin devlet tarafindan gündeme alınmadan uygulamaya geçirilmesi, çalşanlar tarafindan çok çok olumlu karşılanmıştır. Süreçte bireysel mesafeli ilişkiler ve önem ön plana çıkmıştır." şeklinde konu hakkındaki görüşünü bildirmiştir. K15 de bu konuda: "Tabi 
COVID-19 sürecinde bu tip etkinlikler azalma gösterdi çünkü bir arada olunmaması gereken bir döneme girdik aslında insanlarla çok yakm olmamamız gerekiyor. Bu yüzden daha çok toplu olacak şekilde değil de bireysel olacak şekilde etkinliklere dönüşecekmiş gibi görünüyor. Örneğin; bayramlarda çikolata dağıtıllyordu ama şimdi pandemi sürecinde çikolata dağıtılırken yanında maske ve dezenfektan dağgtılacak. Günlük hayatta çalı̧anlarm daha kolay ulaşabileceği takviyeleri vererek onlarm motivasyonunu arttırabilmeyi düşünüyoruz. Mesela biz ilk pandemi başladığında bütün çalışanlarımıza dezenfektanları dağıttık, maskelerini veriyoruz kimse eksik hissetmesin diye bu tarz yardımlarla çalışanlarımızı daha da motive etmeye çalışıyoruz." demiştir. Alt temadan elde edilen bilgilere bakıldığında IKY yöneticilerinin COVID-19 döneminde sosyal mesafeye uygun etkinlikler gerçekleştirdiği, erteledikleri personel moral ve motivasyonunu arttırabilmek için online görüşme, terapi ve internet iletişimini kullanmaları, personelin bu kaygılı dönemi daha rahat atlatmalarına katkı sağladığı söylenebilir.

"Mevcut performans değerlendirme kriterleri ve COVID-19 meydana getireceği değişiklikler" alt temasıyla ilgili olarak katılımcılar tarafından en çok tekrarlanan ifadeler şu şekildedir: "IK ve birim yöneticilerince personele yönelik iş ve yetkinlik odaklı performans değerlendirme sistemi uygulanmaktadır" (K3, K5, K8, K9, K10, K13, K14, K15, K16, K17, K18, K19, K20, K21, K28, K29, K30, K31, $\mathrm{K} 32$, K34, K35, K36, K41, K42, K46, K47, K49 ve K51), "performans değerlendirme yapılmiyor" (K23, K33, K37, K38, K44, K48 ve K50), "yılda bir kez IKKY raporu hazırlanmaktadır" (K2, K26 ve K43), "3 ay, 6 ay, 9 ay ve yillık değerlendirme formlar ve performanslart ölçülmektedir" (K4 ve K22), "6 ayda bir performans değerlendirme yapılmaktadır" (K24, K27 ve K45), "misafirle olan ilişkiler bizim değerlendirme sistemimizdir" (K11 ve K14) "hijyen ve temizlik değerlendirmesi" (K11 ve $\mathrm{K} 14)$, "elektronik psikolojik danışmanlık ve rehberlik (e-PDR)" (K1), "sadece satış departmanına yönelik performans değerlendirilmesi yapılmaktadır" (K6), "Mart ayından itibaren faaliyetler durduğu için değerlendirme yapılmamaktadır" (K7), "Bireysel hedef değerlendirme (KPI)" (K12), " $360^{\circ}$ performans değerlendirme sistemi uygulanmaktadır" (K25), "belli periyotlarla motivasyon görüşmeleri yapılmaktadır" (K39) ve "ayda bir performans değerlendirilmesi yapılmaktadır" (K40). Alt temayla ilgili olarak K5 K8, K9, K10, K31, K32, K34 ve K49 katılımcıları: “COVID19'dan sonra sistemde değişiklik olacağıı düşünmüyorum." diyerek COVID-19 sürecinde değerlendirme sisteminde bir değişiklik olmayacağını belirtirken, diğer katılımcılar, ilgili süreçten sonra değerlendirme sistemleri ve parametrelerde değişiklikler olacağın belirtmiştir. Konu hakkında K48: “COVID-19 
sürecinde genel olarak yanıtlamam gerekirse performans değerlendirme süreçleri tüm şirketlerde değişecektir. Çünkü KFTI dediğimiz hedeflerin güncellenmesi gerekecek. Güncel şartlara göre hedefler değişeceğini düşünüyoruz. Dolayısıyla performans göstergelerinin de değişmesi gerekecek ve performans toplantıları da online yapılacak yüz yüze bir şekilde olmayacak ve en temel değişiklikler bunlar olacaktır." Katılımcilardan alınan görüşler doğrultusunda birçok işletmenin faaliyetlerini azaltması ve/veya durdurmasına bağlı olarak değerlendirme süreçlerinde esneklik olacağı, değerlendirme kriterlerinde internet ve teknolojik gelişmelerden yoğun olarak yararlanılacağı ve iş sağlığı ve güvenlik uygulamalarının önemli kıstasların başında geleceğini düşündürmektedir.

Tablo 3'te, "COVID-19'un İş Planlaması ve Faaliyetlerine Etkisi” temasına verilen cevaplar incelendiğinde, "COVID-19 sürecinde sağlık ve güvenlik açısından, evden çalışma gibi çalışma programlarının desteklenmesi ve çalışanlarla olan iletişimini yaygın bir şekilde internet üzerinden gerçekleştirilmesi" alt temasına verilen cevaplar tekrarlanma sıkılığına göre şu şekildedir: "büro personeli için homeoffice- evden çalışma uygulamasına geçilmiştir" (K1, K2, K5, K6, K7, K8, K9, K10, K12, K14, K15, K16, K17, K18, K19, K20, K21, K22, K23, K24, K25, K26, K27, K28, K29, K30, K31, K32, K33, K34, K38, K39, K41, K42, K43, $\mathrm{K} 44, \mathrm{~K} 46, \mathrm{~K} 47, \mathrm{~K} 48, \mathrm{~K} 50$ ve K51), "hizmet sektörü olunmastna bağh olarak dönüşümlü şekilde fiziki çalışma yöntemi devam etmektedir" (K11, K27, K35, K37 ve $\mathrm{K} 45)$, "imalata dayal işletme olduğumuz için evden çalışma sistemine geçilememiştir" (K13, K15, K40 ve K49), "işletmede ofis çalışanları için dönüşümlü çalışma programı uygulanmaktadır" (K4 ve K36) ve "satış rakamlarında düş̧üş olmaması için evden çalışma sistemine geçilmemiştir" (K3). Konu hakkında katılımcı görüşlerine bakıldığında, K1: "Evden çalışma sisteminde personelde iş disiplininde ve deadline'ı olan acil konularda gevşemeler olabilmektedir. Ancak sorumluluğunu bilen ve evden çalışma sistemini iyi kurabilen personel için hem işletme hem de personel mutlu şekilde çalışmasımı sürdürmektedir. Şimdiye deŏin işletmemizde bu pandemi sürecinde evden çalışmalar yapılmakta olup şimdilik bir sorun ile karşılaşılmamıştır. Özellikle bulaşma riskini sıfıra indirmiş olmaktayız, bu dönem için bu durum çok büyük bir avantajdır, özetle sistem iyi kurulur ve herkes sorumluluğunu iyi bilir ise evden çalışma sistemi bu pandemi sürecinde çok iyi bir sistemdir.", K3: "İşletmemizin açı olduğu zamanlarda müşterilerimiz ve çalışanlarımı arasında sosyal mesafeyi koruyarak, maske ve dezenfektan kullanarak COVID-19 virüsünden korunmaya çalıştık.", K5: "Evden çalışma fikrine, iş să̆hlı̆̆ı ve güvenliğine, her şeyden çok kişilerin 
kendilerini risk altında hissetmeden çalışmasına çok önem veriyoruz. Henüz Türkiye'de vakalar görülmeden önce yabancı ülkelerde bu sayılar artarken bizler zaten personelimizi sürekli kontrol altında tutuyorduk. Personelin yurt dışı seyahatlerine ve Türkiye'de risk grubunda bulunanlarn evinden çalışmalarma yönelik önlemleri almıştık. Bu yönden gerçekten Türkiye'de ilk evden çalışma kararını alan şirketlerden biri biziz diyebilirim. İnternet üzerinden çalısıyoruz. Şirketimizin internet ve on-line alt yapısı çok iyi durumdadır. Bundan dolayı geçiş sürecinde de zorluk yaşamadık.", K8: "Uzaktan çalışan insanlar yolda, asansörde, toplu taşımada geçirecekleri saatleri daha verimli kullanma şansma sahipken, trafik çilesi ve geç kalma stresi gibi olumsuzluklardan da uzaktırlar. Ofisin dikkat dağıtıcı unsurlarından kaçınırlar. İş günlerinde 9-6 mesaisi yerine zamanın kontrolü kendilerindedir. Sevdiklerine, arkadaşlarına ve hobilerine ayırmak için daha fazla zamanlar vardır.", ve K17 ise "Teknolojinin ve dolayısıyla internetin getirdiğgi çalışma kolaylğ̆ı ile her geçen gün sağlık koşullarında, işlerimizi evlerimizden sorunsuz bir şekilde yürütmekteyiz. Takım çalışmalarında iletişim kurmak içi IRC, Discord, Teams; canln iletişim kurmak için Messanger, Zoom, Skype gibi programlar kullanarak işlerimizin aksamasın önlemekteyiz." olarak görüşlerini bildirmiştir. Alt temaya verilen cevaplar incelendiğinde genel olarak çoğu sektörün evden çalışma sistemini benimsediği, imalat ve hizmet sektöründeki işletmelerin bu sisteme, adapte olmakta güçlük çektiği söylenebilir.

"COVID-19 sürecinde çalışanların iş tanımlarında veya iş gerekliliklerinde bir değişim olması" alt temasıyla ilgili olarak tekrarlanma sıklığına göre alınan cevaplar ise aşağıdaki gibidir: "iş tanımlarında ve gerekliliklerinde değiişiklik olacaktı" (K5, K6, K7, K10, K11, K17, K18, K19, K20, K21, K23, K24, K27, K28, K29, K30, K31, K34, K35, K36, K37, K38, K40, K41, K42, K45, K46, K47 ve $\mathrm{K} 49)$, "iş tanımlarında ve gerekliliklerinde değişiklik olmayacaktır" (K1, K3, K4, K8, K9, K12, K13, K14, K15, K16, K22, K25, K26, K32, K34, K39, K43, K44, K48, $\mathrm{K} 50$ ve K51) ve "esnek çalışma saatlerine geçilmiştir" (K2). Alt temayla ilgili katılımcılardan alınan görüşler incelendiğinde, $\mathrm{K} 3$ ve $\mathrm{K} 4$ : “Bu süreçte çalışanlartmızın iş tanımında ve görevlerinde değişiklik olmasından ziyade işletme içi düzenimizi değişstirdik. Müşterilerimizin çalısanlarmmıla aralarındaki sosyal mesafeyi korumalarna özen göstererek iş yerimizde bu doğrultuda düzenlemeler yaptık. Fakat SOP (Standard Operating Procedure) kurallarnda COVID-19 ile ilgili modifikasyonlarm mutlaka yapılması gerekecektir. Ayrica COVID-19 standartlarmm takibi için yeni istihdam edilecek personelin iş tanmlan baştan belirlenecek ve ilgili departmanlar olan Hijyen ve Kalite Departmanı ile `Süreç Takipleri’ tantmlanacaktır.", K5: 
“Türkiye'de hala evrak ve belgelendirme işlemleri eski usul devam etmektedir. Bir belgeye bir imza alabilmek için bile günlerce beklediğimiz olabiliyor. Bu dönemde belki de işlerin daha kısa sürede tamamlanabileceği iş gücünün daha verimli kullanilabileceğgi bu tür detay işlere vakit harcanmayacağını öngörebiliyorum. Örneğin; bir imza için bir saat dolaşmak yerine imza programı ile beş dakikada halledilebilir. E-imza sistemine geçilebilir. Aslında bu dönemde daha verimli çalş̧ılabileceğini düşünüyorum. İnsanların odaklanabilecekleri sosyal hayatları olmadığı için odaklandıkları tek şey sağllklarn ve işleri. Bu dönemde kendi şirketimde mesai saatleri ortadan kalktı. İnsanlar akşam saatleri çalışıyorlar, öğle araları yapmıyorlar. Etraflarnnda sosyalleşecek kimse bulunmadığı için molalarını daha kısa tutuyorlar. Bu nedenle ciddi anlamda verim yükseldi. Bu yüzden çalışma sistemleri bundan sonra on-line ve dijitalleşerek ilerleyebilir diye düşünüyorum.", K27: "Değişimler olacaktır. Mesela güvenlik departmanındaki kişi otelin güvenliğinden sorumlu olduğu için otellere giren kişinin ateşini ölçebilir. Görevlerine bu eklenebilir. Biz şunu düşündük; mutfaktaki personel çalışırken, alanında uzman kişilerce FEB'n'nin kullanmış olduğu salonlardaki televizyonlarda mutfaktaki personeli izleyebilmesi için bir kamera yerleştireceğiz. Bu kamera 7/24 çalşacak. Orada mutfak departmanmidaki personeli izleyebilecektir.", K30: "Özellikle uzaktan çalışma bazı süreçleri olumlu ve olumsuz olarak değiştirecektir. Mevcut katı ofis kural ve gerekliliklerinde değişimler ile birlikte yeni etik kurallarm oluşumu noktasında gelişmeler olacağı düşüncesindeyim. Zoom da toplantı sırasında mikrofon ve kamera kapatılması gerekliliği durumu gibi. Şu an için sadece mikrofon kapatılma durumunu toplantılarda telefon sesini açık bırakma yerine gelecek bir kural olacağın düşünebiliriz. Benzer noktada kamera kapatmanın ise yayın kalitesine önemli bir katkı sağladığın düşünürsek bunun da iletişimde yazıl olmayan bir kural olarak oluşacağını düşünüyorum." ve K43: "Çalışanların fiziksel özellikleri zihinsel özelliklerinden ziyade duygusal ve davranışsal özelliklerinde değişimler olacaktır. Örneğin iletişimsel açıdan önceden misafirlerle birebir göz kontağ̆, birebir temasla hizmet verilmesi gerekiyordu. Ama bundan sonraki süreçte biraz daha mesafe olacă̆ için müşteri memnuniyetsizliğine yol açacaktır. Aynca çalışırken koruyucu tedbirler alnacaktır. Çalışanlarm hijyen, iş sağhı̆̆ı ve güvenliği, pandemi, salgınla mücadele gibi eğitimlerin yanı stra personele psikolojik destek sağlayarak sezona hazır bir şekilde girebilmemiz gerekiyor. Personelin otel içerisindeki çalı̧̧ma şekilleri (sosyal mesafe, maske takılması, siperlik takılması vb.) ile ilgili eğitimleri veriyoruz ve bununla ilgili çalışmaları kalite departmanlarımız organize etmeye ve yürütmeye çalışıyor. Ancak aşı bulunana kadar bunun böyle devam etmesi gerekiyor. Bir nevi pandemiden önce, pandemiden sonra olacaktır." Bu alt temaya verilen cevaplara göre, COVID- 
19'un etkileri neticesinde, İKY yönetici ve uzmanlarınca, iş tanımları ve gerekliliğinde değişiklikler olacağı düşünülmektedir.

"COVID-19 sürecinde insan kaynakları planlamasını yaparken ihtiyaç duyulacak personel sayısı" alt temasında katılımcilar tarafindan verilen cevaplar şu şekildedir: "sürece bağhl olarak personel sayısında azalma olacaktır" (K1, K4, K6, K11, K12, K19, K21, K24, K25, K27, K29, K32, K36, K37, K38, K40, K43, K44, K45, K46, K47, K48 ve K51), "dünyadaki gelişmelere ve sektördeki taleplere bağhl olarak personele ihtiyaç artabilir veyahut tam tersi azalabilir" (K8, K10, K16, $\mathrm{K} 17, \mathrm{~K} 18, \mathrm{~K} 20, \mathrm{~K} 22$, K23, K26, K28, K30, K31, K33, K34, K35 ve K41), "sürece bağlı olarak personel sayısı artacaktır" (K5, K7, K13, K14, K39 ve K50), "sürece bağlı olarak personel sayısı değişmeyecektir" (K3, K9, K15, K42 ve K49) ve "internet üzerinden satış gerçekleştirildiğinden bu süreçte personel sayısı artmıştır" (K2) şeklindedir. Katılımcların konu hakkındaki görüşlerine bakıldığında, K1: "Ülke dolaşımlarn sıfira inmiştir, bu sebeple hem merkez şubemiz olan İstanbul hem de diğer ülke şubelerimiz İtalya, Bosna Hersek, Gürcistan, Afrika'da işler tamamen durmuş bulunmaktadır. Bu süreç içerisinde \%80 personelimiz iş yapamamaktadır.", K4: “COVID-19 sonrası süreci iki kısımda değerlendirmek doğru olacaktır. Yeni normal sürece geçildiği ilk dönemde \%50 kapasite ile çalışacak otellerde doluluk oranlarının da nispeten düşük olacağından dolayı personel sayısında bir tasarrufa gitmek kaçınılmazdır. Fakat tüm şartlarm düzelmesi ve 2019 doluluk oranlarmın yakalanmast ile birlikte COVID19 şartları ekstra yükler ve işletmeler için yeni personel istihdamın gerektirebilir.", K5: "“Yeni başlayan projeler için işe alımlarımı devam etmektedir. Bir azalama söz konusu değildir. COVID-19 süreci bittiğinde, insanlar sosyal hayatlarına, normal iş düzenlerine döndüklerinde alınan projelerde bir artış olur ise personel sayımızda artış olacaktır. Şu anda işlerimizi ofisten çalışıyormuş gibi devam ettirmekteyiz." ve K8: "Üretimi olan firma sürekli personel ihtiyacı duyacaktır. Üretimi az olan işletme de ise personel sayısı azalacaktır." şeklindedir. Verilen cevaplar ve katılımcı görüşleri birlikte değerlendirildiğinde, COVID-19 ile iş kolu ne olursa olsun firmaların personel sayılarında bir azalmaya gideceği, piyasalarda genel olarak yaşanan yavaşlamaların Elde edilen bulgulara göre, katılımcıların büyük bir çoğunluğunca, İKY'de personel sayısında daralma yaratacağı düşünülmektedir. Ayrıca sektörlerde talebe bağlı olarak da personel sayısının artacağı ya da azalacağı da öngörülmektedir.

“COVID-19 sürecinde bir işletmede yapılan farklı işlerin göreceli değerlerinde bir farklılaşma olması" alt temasına verilen cevaplar incelendiğinde; "farkh işlerin değerlerinde değisşiklik olacağın düşünüyorum" (K2, K4, K5, K6, K7, 
K8, K9, K10, K11, K12, K14, K15, K17, K18, K19, K20, K22, K23, K24, K27, K28, K29, K30, K31, K32, K34, K35, K36, K37, K38, K42, K43, K45, K46, K48 ve K50), "farkl işlerin değerlerinde bir değişiklik olacağın düşünmüyorum" (K1, K3, K13, K16, K25, K33, K39, K40, K44, K49 ve K51) ve "iş içeriğine farkllık gösterebilir ya da göstermeyebilir" (K21, K26, K41 ve K47) cevaplarına ulaşıldığı görülmektedir. Katılımcıların konu hakkındaki görüşleri ise K14: "Evet, mesela bugüne kadar COVID-19 tedbiri almamışık. Bu salgın kimsenin önceden üzerinde çalışmalar yaptı̆̆ı bir husus değildi ama artık herkes biraz da olsa bilgi sahibi olmak zorundadır. Finansal açıdan ve müşteri portföyündeki değişiklikler göreceli geçmiş yıllara nazaran değişkenlik gösterecektir. Hijyen ve sağlık konuları ile ilgili iş süreçleri daha önemli hale gelecektir. İleride bu alanlara daha çok yatırm yapmak ve yeni çözümler geliştirmek gerekecektir. Bu süreçte sağhlk ve hijyen konusunda farkllaşan uygulamalar yapabilen otellerin başarll olacă̆ın dü̈sünüyorum." ve K29: "COVID-19 sürecinde bir şeylerin farkına vardık, işleri uzaktan ve nöbetleşe sürdürebiliyoruz. İlerleyen süreçte personelin azalacağını net bir şekilde ortaya koyuyor. İşler biraz daha otomasyona dönüyor uzaktan bağlanıyoruz. İş yapış şekillerimizde değişimler söz konusu olabilir; istihdam etme yani bordrona alma, proje bazh çalş̧tr. Bir nevi insan kaynağı kiralama olarak görülebilir." şeklindedir. Genel olarak ilgili alt tema ve temanın tamamına verilen ifadeler birlikte değerlendirildiğinde, COVID19'un genel olarak sektörlere göre iş tanımı, gerekleri, değerlendirmesi, farklılaştırması ve personel istihdamında değişmelere neden olduğu ve ilerleyen dönemlerde de olacağını söylemek mümkündür.

Tablo 3 incelendiğinde üçüncü tema olan “COVID-19’un İş Planlaması ve Faaliyetlerine Etkisi" teması içerisinde yer alan alt temalara verilen cevaplar incelendiğinde, "COVID-19 sürecinde çalışanların kariyer planlanmalarında, insan kaynakları biriminin gerçekleştirebileceği farklılıklar" alt temasında katılımcılardan alınan cevaplar şu şekildedir: "COVID-19 ile farklılaşma olacă̆ım düşünmüyoruz" (K1, K4, K9, K10, K11, K12, K13, K14, K15, K19, K22, K23, K29, K32, K33, K34, K35, K39, K40, K41, K42, K43, K44, K46, K48, K49 ve K51), "COVID-19 ile farklılaşma olacă̆ın düşünüyoruz" (K2, K3, K6, K7, K8, K16, K17, K18, K20, K21, K24, K25, K26, K27, K28, K30, K31, K36, K37, K38, K45, K47 ve $\mathrm{K} 50)$, "yeni bir program oluşturulacak" (K18, K36, K37 ve K47), "personelin ilgili sürece yönelik yeni yeterliliklerle donatılması planlanıyor" (K8, K38 ve K45), "işe devam konusunda esneklikler sağlanacak" (K16, K21 ve K30), "COVID-19 ile ilgili eğitim ve seminerler verilecek" (K3 ve K7), "pandemiler ile ilgili konferanslar verilecek" (K3 ve K45), "internet üzerinden planlama ve değerlendirmeler yapilacaktır" 
(K6 ve K12), "iç terfi sistemi iyice güçlendirilecek" (K27 ve K46), "bilgi ve beceri eğitimlerinin arttırlması ile farkındalık artacaktır" (K28ve K50), "sakin ve çözüm odaklı olmalı" (K2), "işletmede hali hazırda kariyer planlaması bulunmamaktadır" (K5), "ROTA kariyer planlaması" (K17), "yenilikçiprogramlar tasarlanacak" (K24), "yedekleme toplantıları gerçekleştiriliyor" (K26) ve "insan odaklilı arttırlacak" (K30). Alt temayla ilgili katılımcı görüşlerine bakıldığında, K2: "Hassas süreçler kişilerin yükselmelerinde artı yönler sağlar. Örneğin, durumlara karsı duruş ve çözüm üretmeleri ekip içerisinde sakinlik ve yol göstermeleri, sorun çözme özellikleri bu hassas dönemlerde kendini gösterebiliyor. Bu kişiler tarafimızca gözlem yapılmakta olup uygun zaman ve süreçte olumlu yönde yükseltilmek için planlama yaptlacaktır.", K17: "Program kapsaminda onlarm kariyer beklentileri ile organizasyonumuzun ihtiyaçlarm göz önünde bulundurarak, çalışanlarımıza yönetsel yol ve bireysel katkı sağlayan yol olmak üzere farklı kariyer yolları sunuyoruz. Böylelikle çalışanlarımı kariyer hedefleri doğrultusunda bireysel katkı sağlayan yolda ilerlerken uzmanlĭ̆ın geliştirebiliyor, yönetsel yolda kendisine bağh ekipleri yöneterek takım yönetimi konusunda gelişiyorlar. COVID-19 sürecinde daha çok insan odakl devam ederek planlarımızı ve kullandığımı kariyer programların bu şekilde yürütmeye devam edeceğiz." ve K19: "Kariyer planlamasında, çalışanlar, çok yönlülüğü, teknoloji yatkınlı̆ın ve iletişim becerilerini artırma konusunda daha çok yönlendirmemiz gerekecek. Bu süreç, iş tanımlarnnın ve ihtiyaç duyulan yetkinliklerin her an değiş̧ebileceğini daha net göstermiştir. Bunun için kariyer planlamada esnekliği, daha hızh öğrenmeyi, olumsuz durumlar için B ve C planları hazırlamayı teşvik etmek gerekecektir." şeklindedir. Alt temaya verilen cevaplar ve alınan görüşler dikkate alındığında, kariyer planlamalarında COVID-19'un etkili olabileceği ve ileriki dönemlerde yaşanabilecek farklı pandemilere karşı, proaktif olunması gerekliliği ile kariyer planlamalarına önem verilmesi gerektiği söylenebilir.

“COVID-19 sürecinde çalışanlara ödenen ücretlerde bir farklılaşma olabilmesi" alt temasıyla ilgili olarak katılımcılar tarafından en çok tekrarlanan cevaplar ise "ücretlerde değişiklik olmadan ödenmeye devam edilmektedir" (K8, K9, K10, K11, K12, K13, K17, K19, K22, K24,K25, K26, K29, K31, K35, K38, K39, K40, K42, K43, K44, K46, K49 ve K50), "kısa çalışma ödeneği” (K1, K2, K3, K5, $\mathrm{K} 7, \mathrm{~K} 14, \mathrm{~K} 18, \mathrm{~K} 21, \mathrm{~K} 28, \mathrm{~K} 30, \mathrm{~K} 32, \mathrm{~K} 34, \mathrm{~K} 36, \mathrm{~K} 47$ ve K51), “ücretlerde azaltmaya gidilecek" (K6, K16, K20, K23 ve K45), "ücretsiz izin” (K1, K21 ve K48), “iડşKUR'dan destek almiyor" (K7, K33 ve K37), "yöneticiler için bir değerlendirme yapılacak" (K4 ve K48), "fikrim yok" (K15 ve K41), "averaj ücret aldıklarnndan dolayı 
ara elemanlar için bir değerlendirme yapılmayacak" (K4), "işletme faaliyete başladığında ücret iyileştirilmesine gidilecek" (K14) ve "duruma göre ücretlerde düşüş ve artış gibi değişikliklere gidilecek" (K27) şeklindedir. Katılımcıların tamamına yakını, ücretleri ödemek için kendi sermayelerinden ve devlet desteklerinden yararlanmaya çalıştıklarını, böylelikle iş görenlerini ellerinde tutmaya çalıştığını belirtmiştir. Alt temadan elde edilen bilgilere göre, firmaların iş kollarına göre personeline ücret desteği sağlamaya ve personelini elinde tutmaya çalıştı̆̆ın söylemek mümkündür.

“COVID-19 sürecinde iş güvenliği ve çalışan sağlığı konusunda bir farklılaşma olması" alt temasına verilen cevaplar incelendiğinde, "farklılaşma olacak" (K1, K3, K4, K5, K6, K7, K8, K9, K10, K11, K12, K13, K14, K15, K16, K17, K18, K19, K20, K21, K22, K23, K24, K25, K26, K27, K28, K29, K30, K31, K32, K33, K34, K35, K36, K37, K38, K39, K40, K41, K42, K43, K44, K45, K46, K47, $\mathrm{K} 48, \mathrm{~K} 49, \mathrm{~K} 50$ ve K51), "iş sağhlğ ı ve güvenliği uygulamalarna pandemi eklenerek kapsam artturlacak" (K9, K13, K16, K20, K23, K25, K26, K27, K28, K29,K30, K31, K33, K34, K35, K37, K38, K39, K42, K43, K44, K46, K48ve K49), "hijyen kurallarma uyum, maske, eldiven ve dezenfektan kullanımı" (K5, K10, K11, K15, K19, K24, K28, K31, K32, K36, K37, K40, K42 K47, K49 ve K51), “devletin belirttiği uygulamalar gerçekleştirilecek" (K4, K15, K19, K21, K23, K28, K31, K32, K36, K37, K42, K48, K49 ve K50), "sosyal mesafeye uyum" (K5, K10, K11, K14, K15, K19, K22, K32, K40, K42, K47, K48, ve K49), "günlük sağllk testleri uygulanacak" (K8, K10, K20, K24, K31, K36 ve K38), "COVID-19 ile ilgili eğitimler verilecek" (K1, K14, K15, K16, K28 ve K41), "sağllk ve COVID-19 testi istenecek" (K3, K24, K36 ve K50), "esnek çalışma saat ve ortamları sağlanacak" (K6, K26 ve K49), "Kültür ve Turizm Bakanlığı'nın uygulamalan uygulanacak" (K18 ve K45), "sertifikasyona geçilecek" (K1), "farkhlaşma olmayacak" (K2) ve "konuyla ilgili profesyonel destek alınmaktadır" (K7) şeklinde sıralandığı görülmüştür. Alt temayla katılımcılardan alınan görüşler ise K1: "COVID-19 sertifikaları olmayan personel çalıştırllamayacaktır. Tabi bunlar benim öngörüm, hali hazırda Turizm ve Sağlık bakanlıkları bu çalışmalar üzerinde yoğunlaşmışlardır.", K17: "Yeni yapılan uygulamalar ve kanunlarm hayata geçmesi konusunda paralel olarak çalışmalarına devam etmektedirler. Kurumumuz için 60 maddelik bir önlem çalışması üzerinde durulmakta ve ilerleyen süreçte değişikliklerle birlikte uygulamaya konulacaktır.", K30: "Bu süreç başladığından bu yana en yoğun çalısan birimler İSG ve IK. İkisi de benzer şekilde yeni yapılan uygulamalar ve kanun düzenlemelerini hayata geçirme konu- 
sunda paralel olarak çalışmaktadır. Bizim kurumumuz için yaklaşık olarak 44 maddelik bir önlem çalışması oluşturulması ve süreç değişiklikleri sağlandı. Ayrıca ISGG kapsamında yer alan Acil Eylem Planlarn da tamamıyla yeniden güncellenmiş oldu. Risk ve Kriz kavramlarma yeni boyutlar eklenmiş oldu.", K31: "Türkiye'de ilk vaka görüldükten sonra da çalışanlarmmıa ücretli izin verip, daha sonrasında otelimizi çalışanlar ve misafirlerimizin güvenliği için geçici olarak hizmete kapattık. Bu şekilde gelişen sağlık ve güvenlik önlemlerimiz, otelimiz hizmete tekrar açlldıtan sonra da devam ediyor olacak. Sosyal mesafe kural ve maske kullanımı kurah hayatımızn olmazsa olmazı haline geldiği için bu kural otel hizmet vermeye başladıktan sonra da devam ediyor olacak. Yemekhanemiz de masalarımızm arasında boşluklar bırakacak şekilde düzenleme yapmıştık, çalışanlarımız belli oranda yemekhaneye inip sosyal mesafe kurallarma uyuyordu. Bu durum da aynı şekilde devam edecektir. Dezenfektan, kolonya kullanımı ayn hassasiyetini koruyacaktır. Hijyen ve temizlik en üst seviyede olacaktır. Bunun dışında açık büfe kullanılmayacak, çalışanlarımız misafirlere kendileri servis yapacaklardır. Ateş ölçer cihazlarımızla personelimizin ateşi ölçülecek ve durumlar da yakından takip edilecektir." ve K50: "COVID-19 ile ilgili işyeri özelinde tehlikelerin yeniden belirlenerek ayrı bir risk değerlendirmesinin yapılması veya mevcut risk değerlendirmesinin güncellenmesi gerekmektedir. Risk Değerlendirmesi yapllrken tehlikeler, riskler ve alınacak önlemlerin belirlenmesinde COVID -19 ile ilgili temel ilkeler göz önünde bulundurulacaktır. Çalışanlarn işyerinde nerede ve nasıl COVID-19 virüsüne maruz kalabileceğine ilişkin değerlendirme yapılması, işyerinde işin özelliği nedeniyle yüksek risk altındaki çalışanlarm belirlenmesi, iş süreçleri ve çalışma şekillerinin değerlendirmeler sonucu yeniden planlanması, işyerinde aynı anda bulunan çalışan sayısının asgari oranda tutulması için uzaktan çalı̧̧ma, dönüşümlü çalışma, çalışma süresinin organizasyonu gibi planlanmaların yapılması, maruziyetin azaltılması için, özellikle yemekhane ve dinlenme alanlarında, sosyal mesafenin arttırlmasına ilişkin önlemlerin belirlenmesi, çalışanlarm bireysel risk faktörlerinin (kronik rahatsızlı̆̆ olan çalışanlar, gebe çalışanlar gibi özel politika gerektiren çalş̧anlar vb.) belirlenmesi ve bu çalı̧anların korunması için gerekli tedbirlerin değerlendirilmesi, enfeksiyonun önlenmesi için alınması gereken temel önlemlerin belirlenmesi, hasta kişilerin belirlenmesi ve izolasyonu için politikalar ve prosedürlerin belirlenmesi, gibi süreç işlenecektir." Elde edilen bilgiler ve görüşler dikkate alındığında, IKY yönetici ve uzmanlarının devlet uyarı ve uygulamaları ile kendi koydukları kurallarla iş güveliği ve çalışan sağlığını korumaya çalıştı̆̆ı rahatlıkla söylenebilir. 
Üçüncü temanın son alt teması olan "COVID-19 sürecinde iş güvencesi konusunda bir farklılaşma olması" ile ilgili verilen cevaplar şu şekildedir: "devletin sağladığı sosyal politikalar iş güvencesi sağlayacaktır" (K4, K5, K7, K9, K13, K16, K24, K25, K26, K28, K36, K38, K42, K43, K44, K47, K48 ve K50), "firmamız tarafindan iş güvenceleri korunmaktadır" (K5, K7, K9, K10, K11, K12, $\mathrm{K} 15, \mathrm{~K} 16, \mathrm{~K} 17, \mathrm{~K} 18, \mathrm{~K} 22, \mathrm{~K} 29, \mathrm{~K} 34, \mathrm{~K} 39, \mathrm{~K} 40$, K41 ve K49), “devlet tarafindan getirilen işten çıarma yasağına bağh olarak 3 aylı gü̈venceleri bulunmaktadır" (K1, $\mathrm{K} 3$, K4, K13, K14, K27, K31, K32, K33, K35 ve K45), "çalışan ve iş veren temsilcileriyle görüşmeler yapılacak" (K6, K19, K20 ve K37), "ücretsiz izine ayrılmış personele prim desteği sağlanacak" (K8 ve K21), "sosyal mesafeye uyum" (K2), "işe daha az gelme" (K2), "vardiya sayısı arttırlacak" (K21), "fikrim yok" (K23) ve "dış kaynak kullanıma bağh olarak norm kadrolar azaltılabilir" (K30). Alt temaya bildirilen katılımcı görüşleri ise K5: "Şirketimizde yasal olarak iş güvencesi konusunda bir sıkıntı bulunmamaktadır. Kısa çalışma ödeneğinden faydalanan çalışanlar bu süreç bittikten sonra da bizimle çalışmaya devam edeceklerini biliyorlar. Sürekli bu bilgilendirmeyi yaparak kendilerini rahat hissetmelerini sağhlyoruz. Şirketimiz belirsiz süreli iş sözleşmesi ile çalısmaktadır. İsten çıkış oranı çok düşük seviyededir. Şirketimiz iş güvencesi kültürüne sahip yapıdadır. Çalışanlarımızın iş güvencesi kaygıları bulunmamaktadır. Bir insan kaynakları uzman olarak dışarıda insanların iş ve meslek kaybı kaygısına sahip olduğunu, birçoğunun gelir düzeyinin düştüğünü, iş güvencesinin ne kadar önemli olduğunu anladıklarm düşünüyorum." ve K11: “Bu süreçöncesinde hijyen kurallarna uyum göstermeyen personellerimizi ivedilikle uyartyorduk. Davranışına devam ederse uygun bir biçimde tekrar izah ediyorduk. Fakat iş güvencesi kapsamında hazırlanan sözleşmenin maddelerine yeni bir kural ekleme düşüncesindeyiz. Bu kural, hijyen kurallarına uyum gösteremeyen personelimizin ilk uyarısından sonra hala bu davranışa devam ettiği yönündeyse, işten çıkarmaya kadar gidebilen ek bir madde eklemektir." şeklindedir. Alt temaya verilen cevap ve görüşler, iş görenlerin iş güvencesi ve geleceğinin korunduğunu ve çeşitli desteklerle güçlendirildiğini göstermektedir.

Dördüncü ve son tema olan “COVID-19'un Dış Kaynak Kullanımı, Kullanılan Teknoloji ve Yabancı Uyruklu Personel İstihdamına Etkisi" temasının, "İşletmenin ilerleyen dönemlerde dış kaynak kullanımı (outsourcing) politikalarının ne yönde olacağı ve COVID-19'un bu sürece etkisi" alt temasına verilen cevapların tekrarlanma sıklığına bakıldığında, "dış kaynak kullanımı mevcut" (K4, K5, K7, K8, K9, K10, K12, K14, K15, K16, K18, K19, K21, K24, K25, K29, K31, K32, K35, K36, K37, K39, K40, K41, K42, K43, K44, K45, K46, K47, 
K48 ve K50), "hammadde tedariği" (K7, K9, K9, K10, K12, K14, K15, K16, K21, K24, K25, K26, K27, K28, K32, , K35, K36, K37, K39, K44 ve K47), "isg, sağllkhekim" (K10, K24, K37, K39, K40, K41, K42, K44, K46 ve K48), “dış kaynak kullanımı mevcut değil" (K1, K2, K6, K11, K34, K38 ve K49), "güvenlik" (K9, K18, K19 ve K31), "döviz kurları ve vaka sayıları düşüş gösterirse dış kaynak kullanıminda bulunabiliriz" (K3, K17 ve K30), "temizlik" (K15, K19 ve K43), "eğitim" (K16, K37 ve K45), "servis hizmeti" (K9 ve K29), "fikrim yok" (K23 ve K51), "SPA (Su ile gelen sağlık)" (K4), "çamaşırhane" (K4), "proje hizmetleri alınmaktadır" (K5), "IKY alanında danışmanlik hizmeti" (K7), "catering" (K9), "çevre düzenlemesi" (K10), "dönemin gerekliliklerine göre dış kaynak kullanımı yeniden değerlendirilecektir" (K12) ve "IT (Enformasyon Teknolojileri)" (K13) şeklindedir. Kattlımclardan konu ile ilgili alınan görüşler ise K7, K9, K14, K18, K24, K32, K36, K44, K47, K50: "ISG uzmant ile birlikte dış kaynaklara COVID-19 ile ilgili her türlü kurallarn getirdiği test, işlem ve kontrolünü gerçekleştireceğiz.", K1: "IT gibi birkaç departman için outsourcing hizmeti alabiliriz, bu durumda outsource firmanın üst işvereni olacağımızdan kendilerinin her türlü kanuni zorunluluğunu yerine getirip getirmediklerini denetleyeceğiz ve her türlü ISG, Pandemi kurallarna uygunluklarinı belgeler talep ederek görmüş olacă̆ız.", K21: "Işsletmelerde rekabet avantajı sağlayan faaliyetlere yani en iyi yaptığı işe odaklanması geri kalan işleri ise dış kaynaklardan sağlanması şirketin pazar ortamında kalitesini arttırarak kendi bildiği en iyi işi ortaya çıkarmasımı sağlaması kaçınılmaz bir gerçektir. Pandemi süreci gereğiyle alınan tedbirler neticesinde outsourcing uygulaması devam etmelidir. Çünkü outsourcing uygulamast ile maliyet azalır, temel yetkinliklere odaklanarak mevcudu geliştirmek, riski azaltmak kaliteyi arttırmak temel politika edinilmiştir ve bunlardan vazgeçmek şirket markası adına atılacak adımlar olarak olumlu bir tablo çizmemektedir. Outsourcing uygulamasindan vazgeçilmeyeceği için mevcut duruma ayak uydurmak gerekmektedir. Bu konu üzerine çalışan ne kadar personel varsa gerekli tedbirlerin neler olacağı kısa bir eğitimle anlatılır. Daha sonra alınan tedbirler neticesinde iş planı çıkarılarak bu tedbirlerin uygulanabilirliği test edilerek şirket çalışmasına devam edilmelidir." ve K25: "Firmamiz üretim hammaddesini tamamen ithal etmektedir. Bu süreçte ana ithalatçımı Çin'dir. Yaşanan COVID-19 durumu tarafımıza gelen hammaddelerin süreç olarak uzamasına yol açmıştır. Bu sebepten COVID-19 riskini azaltmak için Almanya ve Rusya'dan hammadde alımı gerçekleştirdik. Bundan sonraki süreç de ithal ettiğimiz ürünlerde COVID-19 kontrolü yapılmış sertifikası aramaktayız bu durumu tedarikçilerimiz ile paylaştık." olarak alınmıştır. Firmaların ağırlıklı olarak dış kaynak kullanımında bulunduğunu ve COVID-19 ile 
gelen şartları, dış kaynak kullanımında dikkate almaya çalıştığı sonucuna ulaşılmıştır.

"COVID-19 sürecinde insan kaynaklarında teknoloji kullanımında bir farklılaşma olması" alt temasıyla ilgili olarak katılımcılardan alınan cevaplar, "dijital iş gücü ve iş sistemleri giderek artacaktır" (K1, K5, K7, K8, K9, K10, K11, K14, K15, K16, K17,K18, K19, K20, K21, K22, K23, K24, K25, K26, K27, K28, K30, K31, K33, K34, K36, K37, K38, K39, K40, K42, K43, K44, K45, K46, K47, K48, K50 ve K51), "online görü̈sme, işgören takibi, iş başvurusu, mülakat, işe alım, toplantilar vb. sistemler kullanilmaktadır ve daha fazla da kullanilacaktır" (K3, K4, K6, K9, K10, K11, K13, K15, K16, K17, K19, K20, K21, K22, K23, K24, K25, K26, K27, K28, K30, K31, K33, K34, K40, K43, K44, K45, K46, K47, K48, K50 ve K51), "uzaktan çalışma sistemi kullanıyoruz ve giderek kullanımı artacak" (K2, K8, K10, K21, K23, K26, K38 ve K39), "uzaktan eğitim" (K10, K16 ve K35), "e-imza" (K8 ve K10), "termal araçlarla ateş ölçümü" (K10 ve K14), "otomasyon sistemleri” (K29 ve K37), "sensörlü araçlar (sııı sabun, dezenfektan, ateş ölçümü)" (K32 ve K36), "farkllık olmayacak ve kullanim ayn seviyede devam edecektir" (K41 ve K49), "online şikayet sistemleri" (K10), "chat boy" (K12), "yapay zeka" (K12), "IT" (K12) ve "temassız ödeme sistemine geçilecek" (K14) şeklindedir. Alt tema hakkında kattlımc görüşleri, K3 ve K4: "Bu sayede iş hayatında kullandığımız kırtasiye ürünlerine olan teması azaltacağız. Yüz yüze yapılması gereken mülakat vb. personel alım yöntemleri de internet üzerinden gerçekleştirilerek gerekli mesafe korunumu sağlanacaktır. Bilgilendirme ve eğitim metinleri dosyalar halinde değil medya sunumları halinde elde edilecektir.", K5: "Bundan sonraki dönemde işlerin daha teknoloji odaklı yapılabileceğini düşünüyorum. Bazı meslekler gelişirken bazı mesleklerin ortadan kalkma noktasina gelebileceğini düşünüyorum. Daha fazla dijitalleşmeye gidilerek daha ucuz iş gücüne ihtiyaç duyulacağın ve sapma olacağını öngörüyorum.", K1: "PDR, mülakat, sözleşme ve işe alım süreçleri, başvuru işlemler vs.", ve K19: "COVID19 sürecinde teknolojinin artan önemiyle birlikte, IK yazılımlarımın, uzaktan çalışmayı kolaylaştınıı teknolojilerin yaygınlığı da artacaktır. Uzaktan çalışmanın performansın ölçmeye yönelik teknolojiler de öne çıkan bir diğer alan olacaktır." olarak kaydedilmiştir. Verilen cevap ve bildirilen görüşlere göre E-IKKY uygulamalarının COVID-19 pandemi döneminde iyice önem kazandığı ve kullanımının yaygınlaştığını söylemek mümkündür. Yapay zeka ve robot teknolojilerinin ilerleyen dönemlerde İKY'de kullanılmaya başlanması da öngörülmektedir. 
Dördüncü temanın son alt teması olan,"COVID-19 sürecinde yabancı personel çalıştırma ve uluslararası insan kaynakları piyasasında değişiklikler olması" alt temasına verilen cevaplar şu şekildedir: "yabancı personel istihdamı şartlara göre değişecektir" (K7, K14, K17, K18, K22, K26, K29, K32, K33, K34, $\mathrm{K} 36, \mathrm{~K} 37, \mathrm{~K} 38, \mathrm{~K} 39, \mathrm{~K} 45$, K47 ve K51), "yabancı personel istihdamı düşecektir" (K3, K5, K6, K8, K16, K19, K20, K21, K25, K30, K31, K35, K43, K46 ve K48), "yabancı personel çalıştırmayı düşünmüyoruz" (K2, K11, K12, K15, K24, K27, $\mathrm{K} 28, \mathrm{~K} 40, \mathrm{~K} 41, \mathrm{~K} 44, \mathrm{~K} 49$ ve K50), "yabancı personel çalıştırmaya devam edeceğiz" (K1, K4, K10 ve K13) ve "fikrim yok" (K9, K23 ve K42)'tur. Katılımclardan konu hakkında alınan görüşlere bakıldığında, K5 ve K6: "Türkiye'de maalesef çalışma izni olmadan sigortasız çalışan birçok yabancı çalışan bulunmaktadır. Bu dönemde bu insanlarm hayatının ne kadar olumsuz etkilediğini gördük. Hiçbir sağllk ve maaş güvencesi olmadan hizmet veren bu insanlarm COVID-19 sürecinden sonra daha azalacağını umut ediyorum. Haklarına uygun olarak işe alımların yapılacă̆ın düşünüyorum. Uluslararası insan kaynakları alanında ise çalışmaya ve hizmete dayalı beyin göçünün bir dönem yavaşlayacağını düşünüyorum. İnsanlar şu anda kendilerini güvende hissettikleri alanı terk etmek istemeyeceklerdir. Bu süreç beyin göçünü yavaşlatacaktır. Ülkeler kendi iç istihdam kaynaklarmı zorlayacaklardır. İç istihdam kaynaklarım kullanmak ülkedeki kalkınmayı hızlandıracaktır.", K11: “Uluslararası insan kaynakları piyasasında ise bir değişim olacă̆ın öngörüyoruz. Yurtdışından gelen personelin ülkeye girdiğindeki karantina süresi gibi faktörler göz önünde bulundurulduğunda, önceki senelere göre yabancı personel alımında azalma olacaktır.", K7: “COVID-19'un üzerimizde yarattığı maddi ve manevi tahribatın büyüklüğ̈̈nü ve vahametinin ne olduğunu ileriki yıllarda çok daha iyi anlayabileceğiz. Uluslararası boyuttaki şirketlerde prosedür neyi gerektiriyorsa öyle davranılacaktır. Zaten yabancı işçi çalıştırma prosedürlere uygunluk ile mümkün olacaktır. Zaman ve koşullar en iyi ilaç olacaktır.", K13: "Mavi yaka için değişim olmaz, beyaz yaka için de şirket faaliyet konusuna göre değ̈işim olabilir. Süreç içerisinde insan kaynakları piyasasının evrensel olarak etkileneceğini düşünmüyorum, bu ancak demin de dediğim gibi şirket faaliyetlerine göre değişebilir. İK piyasası evrensel bir değişime zaman geldiği ve şartlarn gelişmesi gerektiği için gidecektir. COVID-19 bunu etkilemez, etkilememelidir.", K31: “Turizm sektörünü ele alacak olursak, bu oran düşebilir. İnsanlarımı tatil veyahut iş seyahatlerinde bu süreçte yabanc çalışan görünce tedirginlik yaşayabilirler. İnsanlarm ülke değiştirip başka bir ülke de çalısııor oluşu, bu dönem de ülke vatandaşlarmnca pek sağlıklı karşılanmayacaktır. Bu sebeple yabancı çalışan sayısı da azalıyor olacaktır. Ayrıca ülkelerin içinde bulunduğu ekonomik koşullarm 
seyri zamanla daha açık hale geliyor olacaktır. Türkiye' de de ekonomik koşullarm zorluğu zaman içinde daha net ortaya çıkacaktır. Şirketler bu dönemde gelir-gider durumlarnna göre çalışanlarına ödeme yapacaklarn için, maliyeti daha yüksek olacak olan yabancı uyruklu çalışanlara da öncelik vermeyecekleri kanaatindeyim." ve K50: "Biz yabancı personel çalıştırmıyoruz. Ancak; yabancı işçi çalışırma izin belgesi alma usul ve esasları ile, izin belgesi almadan yabancı işçi çalıştırılması durumunda hem işçiye hem de işverene uygulanacak iş sağhl̆̆ı ve güvenliği uygulamalar ve müeyyideler tekrar güncellenmeli. İthalat ve ihracat yapan işverenler yönünden şu an zor bir süreç her şey uzaktan çalışma velveya görüşme ile yapılamıyor. COVID-19 ülkemizde sıfirlansa da diğer ülkelerde devam ediyor olabilecek. Bu nedenle yabancı işçi çalıştırma konusunun askıya alınacağı düşüncesindeyim. Askıya alınmasa da işçi ve işveren yönünden zor bir süreç olacaktır." olarak tespit edilmiştir. Elde edilen cevap ve görüşler birlikte değerlendirildiğinde, COVID-19 döneminde, yabancı personel istihdamının, vaka sayılarının azalmasına ve normalleşme sürecine girilmesine bağlı olduğu söylenebilmekle birlikte, firmalara olan taleplerde meydana gelen daralmalar, ekonomilerini etkilemekte ve bu duruma bağlı olarak istihdam ihtiyaçlarını yerli işgörenlerle sağlama eğiliminde oldukları da söylenebilir.

\section{Tartışma ve Sonuç}

Gündelik hayatta insan, tüketici ve çalışan olarak varlığını sürdürebilmektedir. İnsan doğası gereği varlığını sürdürmek adına çalışmak ve tüketmek durumundadır. Ancak, 2019 yılının sonunda Çin'de patlak veren COVID-19 virüsü dünya çapında insanların ve firmaların faaliyetlerini ve yaşayış biçimleri etkilemiştir. İnsanların hayatlarına yeni kavramlar, yeni uygulamalar kazandıran pandemi döneminde, firmaların faaliyetlerini sürdürmesi ve faaliyetlerinin temelini oluşturan işgücü konusunda yapması gerekenler, son derece önem teşkil etmiştir. Çalışmanın temel amacl; COVID-19 pandemisinin insan kaynakları yönetimi ve faaliyetleri üzerindeki etkilerinin belirlenmesidir. Gerçekleştirilen kaynak taraması neticesinde, yerli ve yabancı literatürde bu güncel konuyu ele alan bir çalışmaya rastlanılamamıştır. Çalışmanın amacıyla, literatürdeki bu boşluğu doldurması hedeflenmektedir.

Çalışmada dikkat çeken sonuçlar arasında firmaların elektronik insan kaynakları uygulamalarına ağırlık vererek, imkanlar dahilinde faaliyetlerini 
sürdürmeye çalıştığı; online iletişim ağı sayesinde çalışanlarla işbirliği ve moral sağlama gayreti içerisinde oldukları görülmektedir. Firmaların, yeni döneme adapte olmak için Dünya Sağlık Örgütü ve devletin konuyla ilgili kurallarını uygulamaya koyma gayreti içerisinde olduğu veya ilerleyen dönemlerde uygulayacağı rahatlıkla söylenebilir. Süreçte evden çalışma sisteminin ağırlık kazanmasıyla, faaliyetlerin mümkün olduğunca elektronik ortamlarda yürütüldüğü işgörenlerin sahip olduğu görev tanımları ve sorumluluklarının da aynı doğrultuda değişime uğradığı görülmektedir.

Pandemi döneminde hayata geçirilen uygulamaların normalleşme sürecinde de devam edeceği özellikle internet kullanımının yaygınlaşması ve dış kaynak kullanımı gibi maliyeti düşüren etmenlerin bu dönemde iyice değer kazanmasıyla işletmelerin faaliyetlerinde ilgili iki unsura ağırlık vereceği çıkarımında da bulunulabilmektedir. Yine bu süreçte firmalar COVID-19 ile hayatımıza giren hijyen, sağlık, sosyal mesafe gibi kurallara riayet ederek, iş sağlığı ve güvenliğini arttırmayı hedeflemektedir. Firmaların mevcudiyetinin çalışan ve tüketicilere bağlı olduğu düşünüldüğünde, sağlıkla ilgili her uygulamanın firmalara değer katacağına dikkat çekilmektedir.

Nitelikli işgücünün elde tutulmasını sağlamak adına ücret, kariyer planlaması, moral ve motivasyon uygulamalarının son derece önemli olduğu, özellikle firmaların çalışanlarını elde tutabilmek adına pandemi döneminde kariyer planlama programlarını gözden geçirmesi gerektiği sonucuna ulaşılmıştır. Klasik yöntemlerin pandemi döneminde yetersiz kalmasıyla elektronik bilgi sistemlerinin kullanımı iyice artmaktadır. Firmalar, ihtiyaç duydukları iş gücünü temin etmede internetten yararlanmakta, değerlendirme, mülakat gibi süreçleri de yine internet aracılığıyla gerçekleştirmektedir.

İlgili süreçte ülkelerin vatandaş ve firmalara sağladığı desteklerin hem vatandaşların sağlığına hem de firmaların faaliyetlerine olumlu katkı sağladığı düşünülmektedir. İmkanlar dahilinde devletlerin kendi halklarına ve firmalardaki çalışanlara sağladığı destekler hem sağlık hem de moral açısından son derece etkili olacaktır. İlgili desteklerin arttırılması, vatandaş ve firmalara sosyal devlet anlayışıyla yaklaşılması önem arz etmektedir. Halk ve vatandaşa devletin elektronik ortamda psikolojik destek sağlaması gerekmektedir. Firmaların da ilgili uygulamaları yürürlüğe koymalarının işgörenlerin firmalara olan aidiyetini arttıracağ 1 düşünülmektedir.

Beklenmedik bir şekilde ortaya çıan COVID-19 pandemisinde firmaların yürürlüğe koymuş olduğu uygulamalardan sürekli olarak yararlanılmalıdır. 
İnsan kaynakları yöneticilerin plan ve programlarını sürekli güncellemeleri son derece önemlidir. COVID-19 sürecinin sona ermesinden sonra normalleşme süreci başlasa dahi başka bir salgın sürecine hazırlıklı olunmasını, en azından firma uygulamalarının sağlam temeller üzerine oturtulmasına katkı sağlayacaktır. Bu sayede firmaların, her duruma karşı proaktif yapıda olabileceği, işgören ve iş faaliyetlerinde minimum kayıp yaşayabilecekleri düşünülmektedir. Belirtilen önerilerin uygulamaya katkı sağlaması da istenmektedir.

Araştırmanın sinırlılıklarıyla ilgili olarak, çalışma konusunun yeni bir kavrama bağlı olması, araştırmada nitel yönteme bağlı olarak yarı-yapıland1rılmış görüşme tekniğinin uygulanması ve katılımcı sayısı ifade edilebilir. İleride konuyla ilgili gerçekleştirilecek çalışmalar için araştırmadaki görüşme formu anket formuna dönüştürülmede kullanılabilir ve bu sayede konuya ilişkin daha çok katılımcıya ulaşılarak daha kapsamlı bir araştırma gerçekleştirilebilir. 


\title{
EXTENDED ABSTRACT
}

\section{Human Resources Management Practices of Businesses in The Era Of COVID-19}

\author{
Ayşen Akbaş Tuna - Onur Çelen \\ Hacı Bayram Veli University, Bursa Uludă̆ University
}

Human Resources Management is a strategically important and continuous process that enables the enterprise to achieve its corporate goals successfully with its workforce, talent, planning, performance, policies and practices. It is obvious that human resources management has many duties to fulfill. Especially in markets where all kinds of changes and events are experienced, businesses have to overcome the negative situations they encounter with the least damage. Adverse health events on a global scale both threaten people's health and negatively affect the assets and activities of businesses. he covid19 epidemic, which began to spread around the world in late 2019, has affected the entire world, bringing the activities of many businesses to a standstill. During the pandemic process, occupational health and safety also constitute other issues related to human resources management. This situation suggests that there will be various changes in human resources management activities. Therefore, the current situation of human resources management and the things to be done according to the relevant situations during this process and for the upcoming periods are extremely important.

The main purpose of the study is to examine the human resources management process of businesses during the COVID-19 outbreak. It is aimed to reveal the opinions on issues such as how businesses are planning and implementing human resources, what should be considered in hiring and personnel recruitment during the pandemic process, what the occupational health and safety practices are, whether there will be an increase or decrease in the number of personnel during the pandemic process. it is also aimed to determine the changes that may occur in Human Resource Management.

In the data collection process of the research, Digital interview technique was used from qualitative research methods. While determining the sample group of the study, "criterion sampling" method, one of the purposeful 
sampling methods, was used. Criterion sampling is the determination of the appropriate individuals from the individuals who create the objects, events or process depending on the problem. In the fieldwork part, care was taken to include managers who are knowledgeable about management, managers of the human resources department in private companies, officials responsible for human resources in the public institution, and NGO managers who have opinions on the subject.

In the study, data set entry process was performed by two different researchers to NVivo 11 package program and then the obtained theme, subtheme and expressions were compared. As a result of the comparisons, it was understood that the Cohen kappa coefficient was 0.88. Cohen Kappa coefficient should be between -1 and +1 . As it approaches +1 , it is concluded that the comparison is reliable, that is, a perfect match. Therefore, it can be said that the themes, subthemes and expressions in the study are reliable. The themes and sub-themes in the study are given below.

1. Current HRM Practices of Businesses and the Effects of COVID-19

a) Policies that you currently applying and will apply to keep your qualified workforce and competent personnel in your field

b) In this period, which channels (newspaper ads, reference-friendfriend advice, educational institutions advice, websites, social media, etc.) to used for staff recruitment

c) What methods (test, interview, health report, etc.) are used in personnel selection in the current period and whether COVID-19 will cause changes in this regard

d) What methods are used in personnel training in the current period and whether COVID-19 will cause changes in this regard

e) Practices performed to increase the motivation of staff and the effect of COVID-19 on related practices

f) Current performance evaluation criteria and changes that COVID-19 will bring

2. The Effect of COVID-19 on Business Planning and Activities

a) In terms of health and safety during the COVID-19 process, supporting work programs such as working from home and communicating with employees widely over the internet

b) Changes in job descriptions or job requirements of employees during the COVID-19 process 
c) The number of personnel that will be needed while planning human resources in the COVID-19 process

d) There is a differentiation in the relative values of different jobs in a business during the COVID-19 process

3. Effects of COVID-19 on Career Planning, Wage, Job Security and Job Evaluation

a) Differences that the human resources department can realize in the career planning of employees in the COVID-19 process

b) There may be a differentiation in wages paid to personnel during the COVID-19 process

c) There is a differentiation in occupational safety and employee health during the COVID-19 process

d) There is a differentiation in job security in the COVID-19 process

4. The Effect of COVID-19 on Outsourcing, Technology and Employment of Foreign Nationals

a) How the outsourcing policies of the company will be in the future and the impact of COVID-19 on this process

b) A differentiation in the use of technology in human resources during the COVID-19 process

c) Changes in the COVID-19 process in both the employment of foreign personnel and the international human resources market

According to the study findings, it was concluded that companies carried out various activities in order to adapt to the relevant process, focused on internet systems in their applications, performed hygiene and health checks for occupational safety of employees, and tried to provide job security to their employees with the supports received from the state and their own means.

It is extremely important that human resources managers constantly update their plans and programs. Even if the normalization process begins after the end of the COVID-19 process, it will contribute to being prepared for another epidemic process, at least to build firm practices on solid foundations. In this way, it is thought that companies can be proactive in every situation and experience minimum loss in employee and business activities. 


\section{Kaynakça / References}

Akbaba, A. ve Günlü, E. (2011). Otel işletmelerinde işgören bulma, seçme ve eğitim sürecinin stratejik insan kaynakları bakış açısıyla değerlendirilmesi: Beş yıldızlı otellerde bir araştırma. Sosyal Ekonomik Araştırmalar Dergisi, 11(22), 199228.

Akbaş Tuna, A. (2020). Örgütsel kısıtların görev performansı ve bağlamsal performans üzerindeki etkisinde örgütsel özdeşleşmenin aracılık rolü. İşletme Araştırmaları Dergisi, 12 (2), 1834-1847.

Alcan, E. (2019). Insan kaynakları yönetiminde bilgi teknolojilerinin kullanımı. Yayımlanmamış Yükseklisans Tezi, Marmara Üniversitesi Sosyal Bilimler Enstitüsü, İstanbul.

Allahverdi, M. (2006). Elektronik insan kaynakları yönetimi ve Türkiye'deki uygulamalarna yönelik bir araştırma. Yayımlanmamış Yükseklisans Tezi, Selçuk Üniversitesi Sosyal Bilimler Enstitüsü, , Konya.

Altınöz, M. (2018). Yetenek yönetiminin algılanması üzerine karşılaştırmalı bir araştırma. Selçuk Üniversitesi Sosyal Bilimler Enstitüsü Dergisi, 39, 82-95.

Altunay, E., Oral, G. ve Yalçınkaya, M. (2014). Eğitim kurumlarında mobbing uygulamalarına ilişkin nitel bir araştırma. Sakarya Üniversitesi Ĕ̆itim Bilimleri Enstitüsü Dergisi, 4(1), 62-80.

Akçadağ, S. ve Özdemir, E. (2005). İnsan kaynakları kapsamında 4 ve 5 yıldızlı otel işletmelerinde iş tatmini: İstanbul'da yapılan amprik bir çalışma. Kocaeli Üniversitesi Sosyal Bilimler Enstitüsü Dergisi, 10(2), 167-193.

Bayraç, A. (2008). İşletmelerde stratejik insan kaynakları yönetiminde eğitim ve geliştirme. Yayımlanmamış Yükseklisans Tezi, Selçuk Üniversitesi Sosyal Bilimler Enstitüsü, Konya.

Bek, H. (2002). Insan kaynakları yönetiminde eğitim ve geliştirme etkinliği: Örnek bir uygulama. Yayınlanmamış Yükseklisans Tezi, Selçuk Üniversitesi Sosyal Bilimler Enstitüsü, Konya.

Benli, A. ve Şahin, L. (2004). İnsan kaynakları yönetiminde işgören bulma ve seçme: Çınar Hotel uygulaması. Bilgi Dergisi, 8, 113-114.

Çelen, O.ve Tuna, M. (2018). Türkiye'deki gurmelerin ınstagram hesaplarının içerik analizi yöntemiyle incelenmesi. Journal of Tourism and Gastronomy Studies, Special Issue, 411-436.

Davuoğlu, N. A. (2018). Sanayi 4.0'in liderlik ve insan kaynakları yönetimine algısal etkileri. Journal of Social and Humanities Research, 15(30), 4041-4048. 
Demirkaya, H. (2006). Tarım toplumundan bilgi toplumuna insan kaynakları yönetiminde değişim. Erciyes Üniversitesi İktisadi ve İdari Bilimler Fakültesi Dergisi, 27, $1-23$.

Dengiz, O. (2017). Endüstri 4.0: Üretimde kavram ve algı devrimi. Makine Tasarm ve Imalat Dergisi, 15(1), 38-45.

Dereli, B. (2005). Çokuluslu işletmelerde insan kaynakları yönetimi. İstanbul Ticaret Üniversitesi Sosyal Bilimler Dergisi, 4(7), 59-81.

Dülek, M. E. (2018). Yöneticilerin E-insan kaynaklar yönetimi uygulamalarından duyduğu memnuniyet. Yayımlanmamış Yükseklisans Tezi, Gaziantep Üniversitesi Sosyal Bilimler Enstitüsü, Gaziantep.

Esen, M. (2011). Bireysel ve kurumsal hazıroluşun teknoloji kabulüne etkisi: Elektronik insan kaynaklar yönetimi (E-IKY) alanında ampirik bir araştırma. Yayımlanmamış Doktora Tezi, Kocaeli Üniversitesi Sosyal Bilimler Enstitüsü, Kocaeli.

Ferecov, R. (2003). İnsan kaynaklan yönetiminde performans değerleme yöntemleri. Dumlupinar Üniversitesi Sosyal Bilimler Dergisi, 8, 07.05.2020 tarihinde https://dergipark.org.tr/tr/pub/dpusbe/issue/4750/65249 adresinden erişilmiştir.

Filizöz, B. ve Orhan, U. (2018). İnsan kaynakları yönetimi bağlamında endüstiri 4.0: Bir yazın çalışması. Cumhuriyet Üniversitesi İktisadi ve İdari Bilimler Fakültesi Dergisi, 19(2), 110-117.

Göktaş, P. ve Baysal, H. (2018). Türkiye'deki dijital insan kaynakları yönetiminde bulut bilişim. Süleyman Demirel Üniversitesi İktisadi ve İdari Bilimler Fakültesi Dergisi, 23(4), 1409-1424.

Gürbüz, S. ve Bekmezci, M. (2012). İnsan kaynakları yönetimi uygulamalarının bilgi işçilerinin işten ayrılma niyetlerine etkisinde duygusal bağllık düzeyinin aracllı rolü. İstanbul Üniversitesi İsletme Fakültesi Dergisi, 41(2), 189-213.

Helvacioğlu, N. ve Özutku, H. (2010). Külttürel farklılıkların yönetiminde insan kaynakları stratejilerinin rolü: IKEA örneği. Yönetim Bilimleri Dergisi, 8(1), 195216.

Huselid, M. A., Jackson, S. A ve Schuler, R. S. (1997). Technical and strategic human resource management effectiviness as determinants of firm perfomance. Academy of Management Journal, 40(1), 171-188.

Karacan, E.ve Erdoğan, Ö. N. (2011). İşçi sağllğı ve iş güvenliğine insan kaynakları yönetimi fonksiyonları açısından çözümsel bir yaklaşım. Kocaeli Üniversitesi Sosyyal Bilimler Enstitüsü Dergisi, 21(1), 102-116. 
Koçak, O. ve Erdoğan, Z. B. (2011). Bankacllık sektöründe yeni insan kaynakları yönetimi yaklaşımları hakkında bir uygulama. Sosyal Siyaset Konferansları Dergisi, 60, 259-283.

Küçükkaya, G. (2006). Insan kayankları yönetiminde personel seçimi ve bir uygulama. Yayımlanmamış Yükseklisans Tezi, Marmara Üniversitesi Sosyal Bilimler Enstitüsü, İstanbul.

Mikhaylov, F., Kolesnikova, J. and Eldar, S. (2014). Current tendencies of the development of service of human resources management. Procedia-Social and Behavioral Sciences, 150, 330-335.

Lendzion, J. P. (2015). Human resources management in the system of organizational knowledge management. Procedia Manufacturing, 3, 674-680.

Olivas-Lujan, M. R., Ramirez, J. and Zapata-Cantu, L. (2007). E-HRM in Mexico: Adapting innovations for global competitiveness. International Journal of Manpower, 28(5), 418-434.

Özer, P S., Özmen, Ö. ve Saatçioğlu, Ö. (2004). Bilgi yönetiminin etkililiğinde kilit bir faktör olarak bilgi işçileri ve insan kaynakları yönetiminin farklılaşan özellikleri. Dokuz Eylül Üniversitesi Sosyal Bilimler Enstitüsü Dergisi, 6(1), 254-275.

Öztürk, A. T., (2010). İnsan kaynakları yönetiminde performansa dayalı ücret ve teşvik sistemi. Organizasyon ve Yönetim Bilimleri Dergisi, 2(2), 1-10.

Parham, S. and Tamminga, H. (2018). The adaptation of the logistic industry to the fourth industrial revolution: The role of human resource management. Journal of Business Management \& Social Sciences Research, 6(9), 179-191.

Pehlivan, B. (2008). İnsan kaynakları yönetimide performans değerlendirmesi ve maliye bakanlığı çalışanlarına yönelik bir uygulama. Maliye Dergisi, 154 171-187.

Ruel, Huub J. M., Bondarouk, T. V. ve Looise, J. K. (2004). E-HRM: Innovation or 1rritation. An Explorative emrical study in five large companies on web-based HRM. Management Revue, 15(3), 364-380.

Ruel, Huub J. M., Bondarouk, T. V. veVan der Velde, M. (2007). The contribution of e-HRM to HRM effectiveness result from a quantative study in a Dutch Ministry. Employee Relations, 29(3), 280-291.

Saldaml, A. (2008). İnsan kaynakları yönetiminde bilişim teknolojisinin kullanımına yönelik bir araştırma: Tekirdağ örneği. İstanbul Ticaret Üniversitesi Sosyal Bilimler Dergisi, 7(13), 239-263.

Sevim, S. ve Ayvac, H. Ş. (2020). Öğretmen adaylarının sosyo-bilimsel konulardaki inançları: Nükleer enerji. Eskişehir Osmangazi Üniversitesi Türk Dünyası Uygulama ve Araştırma Merkezi ESTÜDAM Eğitim Dergisi, 5(1), 25-39. 
Taşlıyan, M., Arı, N. Ü. ve Duzman, B. (2011). İnsan kaynakları yönetiminde kariyer planlama ve kariyer yönetimi: IÏBF Öğrencileri üzerinde bir alan araştırması. Organizasyon ve Yönetim Bilimleri Dergisi, 3(2), 231-241.

Tuna, M., Çelen, O., Aydın, M. ve Özkan, B. İ. (2018). Kilis İlinin UNESCO yaratıc şehirler ağı kapsammnda değerlendirilmesi. Eurasian Academy of Sciences Social Sciences Journal (International Refereed Indexed), Special Issue, 366-388.

Tütüncü, Ö. ve Demir, M. (2003). Konaklama işletmelerinde insan kaynakları kapsamında işgücü devir hızının analizi ve Muğla Bölgesi örneği. Dokuz Eylül Üniversitesi Sosyal Bilimler Enstitüsü Dergisi, 5(2), 146-169.

Ünal, A. ve Çelen, O. (2018). Türkiye'deki otel işletmelerinin web sitelerinin değerlendirilmesine yönelik nitel bir araştırma. Balkesir Üniversitesi Sosyal Bilimler Enstitüsü Dergisi, 21(40), 607-636.

Yapıcı-Akar, N., Dirlik, O., Kıymalığlu, A. ve Yurtseven, Ö. (2011). Uluslararası insan kaynakları yönetimi alanındaki güncel eğilimlerin stratejik yaklaşımlar ve bölgesel modeller açısından değerlendirilmesi: 1998-2008 kesitinde bir inceleme. Business and Economic Research Journal, 2(4), 97-113.

Yıldız, E. ve Davutoğlu, N. A. (2018). Konaklama işletmelerinde personel ve insan kaynakları yönetiminden, Sanayi 4.0'lı yönetime.SETSCI Conference Indexing System, 3, 1563-1569.

Yılmaz, C. ve Erkollar, A. (2018). Endüstri 4.0'ın insan kaynakları planlamsı üzerine etkileri. 5th International Management Information System Conference, 24-26 Ekim Ankara. $\quad \underline{\text { https://imisc.figshare.com/artic- }}$ les/Endu stri 40 n I nsan Kaynaklar Planlamas U zerine Etkileri/7581737 adresinden erişilmiştir.

\section{Kaynakça Bilgisi / Citation Information}

Akbaş Tuna, A. ve Çelen, O. (2020). Covid-19 salgın hastalık sürecinin işletmelerin insan kaynakları yönetimi uygulamaları üzerindeki etkileri. OPUS-Uluslararası Toplum Araştırmaları Dergisi, 16(30), 2710-2759. DOI: 10.26466/opus.781324 